\title{
Expression of recombinant antibodies
}

\section{André Frenzel *, Michael Hust and Thomas Schirrmann}

Abteilung Biotechnologie, Institut für Biochemie, Biotechnologie und Bioinformatik, Technische Universität Braunschweig, Braunschweig, Germany

\section{Edited by:}

Danièle Altschuh, Centre National de la Recherche Scientifique, France

\section{Reviewed by:}

John D. Colgan, University of lowa USA

Andrea Gorlani, University of

California Irvine, USA

\section{*Correspondence.}

André Frenzel, Department of

Biotechnology, Institute of

Biochemistry, Biotechnology and

Bioinformatics, Technische Universität

Braunschweig, Spielmannstr. 7, 38106

Braunschweig, Germany

e-mail: andre.frenzel@

tu-braunschweig.de
Recombinant antibodies are highly specific detection probes in research, diagnostics, and have emerged over the last two decades as the fastest growing class of therapeutic proteins. Antibody generation has been dramatically accelerated by in vitro selection systems, particularly phage display. An increasing variety of recombinant production systems have been developed, ranging from Gram-negative and positive bacteria, yeasts and filamentous fungi, insect cell lines, mammalian cells to transgenic plants and animals. Currently, almost all therapeutic antibodies are still produced in mammalian cell lines in order to reduce the risk of immunogenicity due to altered, non-human glycosylation patterns. However, recent developments of glycosylation-engineered yeast, insect cell lines, and transgenic plants are promising to obtain antibodies with "human-like" post-translational modifications. Furthermore, smaller antibody fragments including bispecific antibodies without any glycosylation are successfully produced in bacteria and have advanced to clinical testing. The first therapeutic antibody products from a non-mammalian source can be expected in coming next years. In this review, we focus on current antibody production systems including their usability for different applications.

Keywords: recombinant antibody, procaryotes, yeast, fungi, insect cells, mammalian cell, transgenic organisms

\section{INTRODUCTION}

Today, antibodies are used for several applications in research, diagnostics, and therapy. They are used in many standard assays such as immunoblot, flow cytometry, or immunohistochemistry. In addition this, the emerging field of proteome research has a huge need of binders against different protein antigens and splice variants $(1,2)$. Moreover, recombinant antibodies are used for the diagnosis of different pathogens $(3-5)$ or toxins $(6,7)$. In the past decade, several antibodies for therapeutic applications have been developed $(8,9)$, primarily targeting inflammatory or tumor diseases (10). In 2010, sales of approved therapeutic monoclonal antibodies in the USA and EU reached 50 billion US dollars (11).

For the detection of different antigens, polyclonal antibodies are widely used in research and diagnostics. These sera contain a large and diverse amount of different antibodies with unknown specificities. However, polyclonal non-human antibodies may exhibit an immune response in human beings that hampers the therapeutic use for example after snake bites (12). Therefore, the production of monoclonal antibodies (mAbs) by hybridoma technology was a significant milestone (13) for the generation of antibodies for therapeutic use. As this technology is based on the fusion of antibody producing spleen cells from immunized mice or rats with immortal myeloma cell lines, its main obstacle is the inefficient immune response to highly toxic or conserved antigens. In addition, nearly all antibodies which are currently in clinical development are of human-origin or at least humanized in some aspect $(9,14,15)$ to prevent immunogenicity. Consequently,

Abbreviations: IgG, immunoglobulin G; mAb, monoclonal antibody. transgenic animals, especially mice, have been developed which contain a human immunoglobulin gene repertoire $(16,17)$ solving the problem of immunogenicity but not the need of an efficient immune response after immunization. Finally, in vitro selection technologies such as antibody phage display or ribosomal display provide a solution for the generation of human antibodies (18-22).

These new antibody generation technologies have increased the amount of antibodies for different applications and, therefore, also the need of efficient production systems. Immunoglobulin $G(\operatorname{IgG})$ is a heterotetrameric molecule consisting of two heavy and two light chains, respectively, which are connected via disulfide bonds. Heavy and light chains (HC and LC) also contain intramolecular disulfide bonds for stabilization (23). These structural properties require a sophisticated folding apparatus as well as an oxidizing environment for the generation of disulfide bonds. Consequently, many traditionally expression hosts do not provide these mechanisms for efficient production of IgGs. Therefore, smaller antibody fragments have been developed which combine easier production with full antigen binding capacity of an $\operatorname{IgG}$ (Figure 1). In addition, the development of smaller fragments was the basis for most of the in vitro antibody generation systems (18-22). These antibody fragments can be used for applications, where epitope binding is sufficient for the desired effect including therapeutic applications such as virus neutralization or receptor blocking.

The smallest antigen binding fragment of immunoglobulins maintaining its complete antigen binding site is the Fv fragment, which consists only of variable (V) regions. A soluble and flexible amino acid peptide linker is used to connect the $\mathrm{V}$ regions to a scFv (single chain fragment variable) fragment for stabilization of the molecule (24), or the constant (C) domains are 


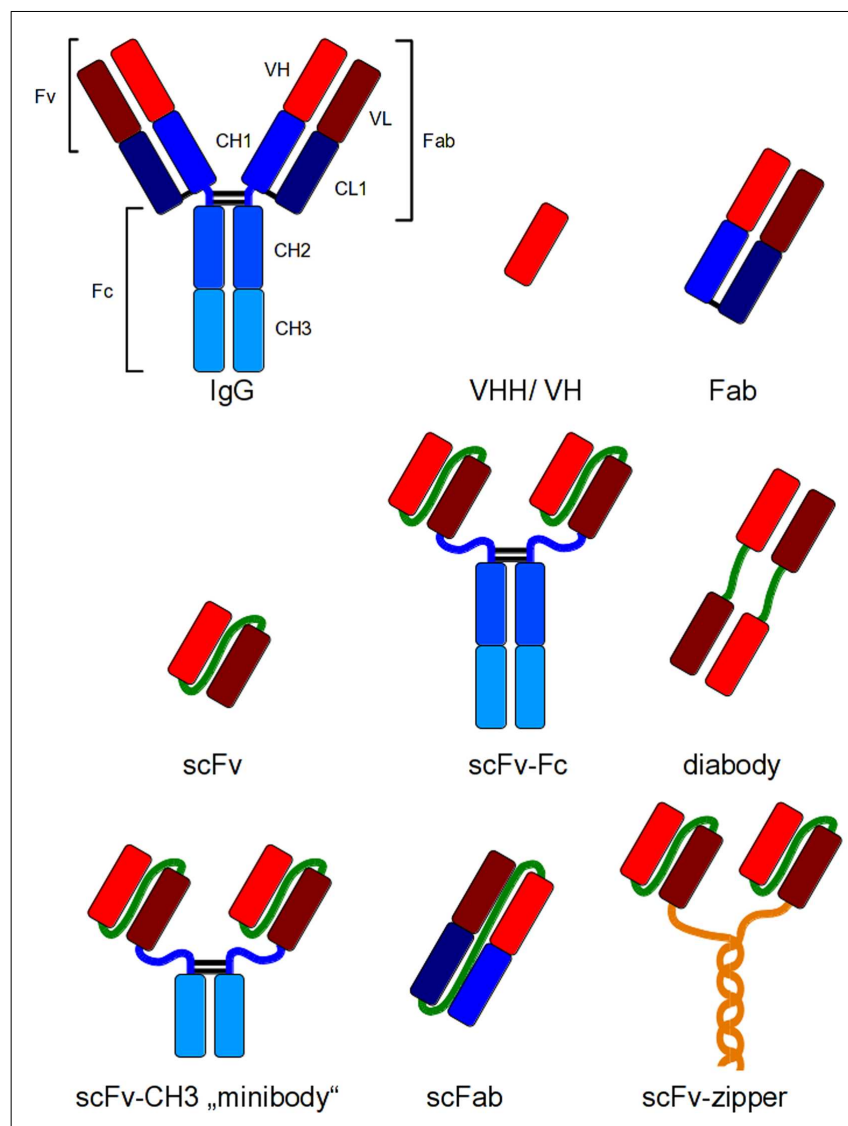

FIGURE 1 | Recombinant antibody formats for different applications compared to IgG. Red and dark red: variable regions; blue: constant regions; green: artificial peptide linkers; yellow: $\mathrm{dHLX}$ represents amphiphatic helices used for dimerization of scFv fragments.

added to the $\mathrm{V}$ regions to obtain a Fab fragment (Figure 1). Today, scFv and Fab are the most widely used antibody fragments which are produced in prokaryotes. Other antibody formats have been produced in prokaryotic and eukaryotic cells, for example, disulfide-bond stabilized scFv (ds-scFv) (25), single chain Fab fragments ( $s c F a b)$ combining $s c F v$ and Fab properties (26) as well as di- and multimeric antibody formats like dia-, tria-, or tetra-bodies $(27,28)$ or minibodies (miniAbs) comprising different formats consisting of scFvs linked to oligomerization domains like immunoglobulin $\mathrm{CH}_{3}$ domain (28), leucin zipper, helix turn helix motif streptavidin, or scFv-scFv tandems (29-31). Bispecific antibody formats combine two different antigen binding domains in one molecule (32-34). The smallest antibody fragments are $\mathrm{V}_{\mathrm{HH}} \mathrm{s}$ of cameloide heavy chain antibodies (35) and single domain antibodies (dAb) $(36,37)$.

For most therapeutic applications, the Fc moiety of an immunoglobulin is essential for the method of action as it mediates the effector functions such as cellular dependent cytotoxicity or the activation of the complement system. Therefore, antibody fragments have been fused to the Fc domain to regain effector functions and avidity $(38,39)$. Figure 1 depicts some of these antibody formats that have been developed for different applications.

\section{ANTIBODY PRODUCTION IN PROKARYOTIC HOSTS GRAM-NEGATIVE BACTERIA}

Escherichia coli is the most important production system for recombinant proteins reaching volumetric yields in the gram per liter scale for extracellular production (40-42). For production of functional antibody fragments, the key to success was the secretion of both $\mathrm{V}$ chains into the periplasmic space of $E$. coli where the oxidizing environment allows the correct formation of disulfide bonds and the assembly to a functional Fv fragment (43). This strategy also allowed the first expression of functional Fab fragments in E. coli described in 1988 (44).

The production of recombinant antibodies in the reducing cytoplasmic compartment results mostly in non-functional aggregates (45). Recovery of functional antibody fragments from cytoplasmic inclusion bodies by complete denaturation and refolding (46) is often not efficient. Stable cysteine free mutants of some scFvs were successfully produced in the cytoplasm of E. coli (47, 48). E. coli strains with mutations in the glutathione and thioredoxin reductase in combination with coexpression of cytoplasmic chaperones GroEL/ES, trigger factor, DnaK/J as well as signal sequence-less variants of periplasmic chaperones DsbC and Skp increased the yield of functional Fab (49).

For the production of camelid single domain antibodies (VHH), coexpression of Ervlp sulfhydryl oxidase increased the yield in the cytoplasm (50).

Despite these efforts, most antibody fragments are produced in the periplasm of $E$. coli using N-terminal leader sequences targeting the periplasmic Sec pathway (51), for example signal peptides derived from outer membrane protein A (OmpA), alkaline phosphatase A (PhoA), or pectate lyase B (PelB) (52-54). Also the SRP pathway can be used for antibody fragment production (55). After expression, recombinant antibodies are usually isolated from the periplasmic fraction $(56,57)$ but also from the culture supernatant (58-61).

The yield of functional scFv fragments has been improved by co- or overexpression of GroES/L, peptidyl prolyl-cis,transisomerase $\mathrm{FkPa}$, or other folding helper proteins (62-66). Functional expression can also be increased by optimization of cultivation parameters, such as temperature, media, or additives. Here, the optimal parameters are dependent on the individual antibody fragment $(58,67)$. The production system itself influences the production rate. Very high yields of antibody fragments produced in E. coli are mainly provided by high-cell density fermentation in bioreactors: the expression of a hapten-specific scFv produced in a bioreactor (68) lead to yields up to $1.2 \mathrm{~g} / \mathrm{L}$ compared to $16.5 \mathrm{mg} / \mathrm{L}$ yield of the same antibody obtained by optimized shake flask production (69), which can be mostly addressed to the over 100-fold higher cell density in the bioreactor. A recent production system is the LEX bubble column bioreactor. Yields in the LEX system of an anti-MUC1 scFv was $\sim 30-40 \times$ higher and yields of an anti-lysozyme antibody was about $2 \times$ higher compared to shake flask incubation $(67,70)$. E. coli strain optimization, e.g., plasmid stability, can additionally improve production yield (71).

The Fab format requires expression, periplasmic transport, correct folding, and assembly of two different polypeptide chains. Among the different vector formats and arrangements, bicistronic vectors with the first cistron encoding the light chain and the 
second cistron encoding the Fd fragment are optimal (56). Even aglycosylated full-size IgGs were successfully produced in E. coli $(72,73)$. In our view, the raison d'être of complete IgG production in E. coli is doubtful.

Cell wall-less L-forms of the Gram-negative bacterium Proteus mirabilis were used for the production of miniAbs and scFv (30, 74), but yield of total $\mathrm{scFv}$ and of functional $\mathrm{scFv}$ were different and ranged from 83 to $127 \mathrm{mg} / \mathrm{L}$ of total scFv to just $9-12 \mathrm{mg} / \mathrm{L}$ of functional $\mathrm{scFv}(74)$. However, quite recently $\mathrm{scFv}$ were produced successfully in Pseudomonas putidas with a yield of $0.5-3.6 \mathrm{mg} / \mathrm{L}$. Interestingly, production yields were decreased by using $\mathrm{scFv}$ genes codon optimized for P. putidas (75).

\section{GRAM-POSITIVE BACTERIA}

Gram-positive bacteria directly secrete proteins into the medium due to the lack of an outer membrane which could facilitate production of antibody fragments. The Gram-positive bacteria Bacillus brevis $(76,77)$, Bacillus subtilis $(78,79)$, and Bacillus megaterium (80-85) have already been successfully used for the production of different antibody fragments. In addition, B. megaterium does not produce alkaline proteases and provides high stability of plasmid vectors during growth allowing stable transgene expression during long term cultivation in bioreactors (86).

Lactobacilli are also tested for antibody production and are "generally regarded as safe" (GRAS) microorganisms. To date, two lactobacillus strains were used for the production of scFvs, Lactobacillus zeae/casei $(87,88)$, and Lactobacillus paracasei $(35,89)$. The GRAS status of lactobacilli allows their direct use for oral application for example for production of anti-Streptococcus mutans antibody fragments to prevent tooth decay (88).

\section{EUKARYOTIC HOSTS USED FOR ANTIBODY PRODUCTION YEASTS}

Eukaryotic cells have developed an advanced folding, posttranslational, and secretion apparatus which enhances the secretory production of antibodies, including full immunoglobulins compared to bacteria. Yeasts combine the properties of eukaryotic cells short generation time and ease of genetic manipulation with the robustness and simple medium requirements of unicellular microbial hosts. Moreover, yeasts have been used for fermentation in food production for several millennia in human history; they do not produce bacterial endotoxins and have gained the GRAS status paving the way toward production of therapeutic proteins (90, 91). Pichia pastoris represents the major yeast strain used for recombinant antibody production (92). Other yeasts like Saccharomyces cerevisiae, Hansenula polymorpha, Schizosaccharomyces pombe $(93,94)$, Schwanniomyces occidentalis, Kluyveromyces lactis, and Yarrowia lipolytica (95) have also been described for protein production but have played only a minor role. P. pastoris shows overall optimal capacity for the production and secretion of heterologous proteins than $S$. cerevisiae and does not secrete large amounts of its own protein which simplifies the downstream processing. Moreover, $P$. pastoris prefers respiratory growth resulting in high-cell densities of more than $100 \mathrm{~g} / \mathrm{L}$ dry weight (96). Probably the most prominent feature of $P$. pastoris is the metabolization of methanol as sole carbon source. The alcohol oxidase 1 (AOX1) promoter is strictly controllable by methanol and commonly used for recombinant protein expression. The secretory production of heterologous proteins including antibodies requires an aminoterminal signal sequence targeting the yeast's secretory pathway. $S$. cerevisiae mating factor alpha (alpha-factor) pre-pro peptide is the most commonly used secretory signal sequence and is followed by appropriate proteolytic cleavage sites sensitive for the Golgi resident endoprotease KEX2 for efficient release of antibodies during secretion, which is often used in combination with ST13 exoprotease sites (97).

Expression of scFv antibody fragments in P. pastoris was first shown by Ridder et al. in 1995 (98). Yields for different scFvs ranged from $70 \mathrm{mg} / \mathrm{L} \mathrm{(99)} \mathrm{to} 250 \mathrm{mg} / \mathrm{L} \mathrm{(100).} \mathrm{Up} \mathrm{to} 8 \mathrm{~g} / \mathrm{L}$ functional scFv were obtained under optimized conditions in bioreactors with coexpression of BiP (101). Llama VHHs achieved over $100 \mathrm{mg} / \mathrm{L}$ yield in S. cerevisiae even in shake flask cultivation (102). Production of more complex, yet still single-gene-encoded formats such as dimeric $\mathrm{scFv}-\mathrm{Fc}$ antibodies in $P$. pastoris achieved production levels of $10-30 \mathrm{mg} / \mathrm{L}$ (103). Antibody formats encoded by two genes such as Fab and IgG required the fusion of the two different antibody chains to the aminoterminal secretory signal sequence and their cotransformation. The yield of Fabs produced in yeast ranged from 1 to $50 \mathrm{mg} / \mathrm{L}$ by shake flask cultivation and up to $0.5 \mathrm{~g} / \mathrm{L}$ in bioreactors (96).

Limited data concerning full-sized IgG expression in yeast is available. In an early study, a mouse-human chimeric antibody and its Fab fragment were produced in S. cerevisiae with a yield of 50-80 $\mu \mathrm{g} / \mathrm{L} \mathrm{IgG}$ and $200 \mu \mathrm{g} / \mathrm{L} \mathrm{Fab}$, respectively. The chimeric IgG mediated tumor specific binding and ADCC (antibody dependent cellular cytotoxicity) but no CDC (complement dependent cytotoxicity) (104). Using P. pastoris up to $1.4 \mathrm{~g} / \mathrm{L}$ of a human IgG1 could be expressed in a 40 -L bioreactor (105).

Lower transformation rates compared to E. coli must be considered for antibody library generation rather than for antibody production. Moreover, the frequency of homologous transformation in yeast is higher compared to higher eukaryotes facilitating the process of making stable expression clones. Specific issues of heterologous protein expression in yeast can be circumvented by optimizing gene sequences, for example by avoiding AT-rich stretches which can cause premature transcriptional termination. The productivity of antibody fragments in yeasts was increased by DNA shuffling (106).

Inefficient secretion of larger heterologous proteins $(>30 \mathrm{kDa})$, proteolysis of secreted proteins during high-cell density fermentation, and inappropriate glycosylation of human glycoproteins are serious issues which required engineering of yeast strains. Overexpression of the chaperone immunoglobulin binding protein (BiP) or protein disulfide isomerase (PDI) in S. cerevisiae increased $\mathrm{scFv}$ secretion titers twofold to eightfold, with an average yield of $20 \mathrm{mg} / \mathrm{L}$ in shake flask culture (107). Yeasts tend to hyperglycosylate heterologous proteins even at positions not glycosylated in the native mammalian host, which can influence activity of antibodies and is a potential source of immunogenicity or adverse reactions in human patients. $P$. pastoris exhibits much lower hyperglycosylation than $S$. cerevisiae, and its $N$-linked carbohydrate structures are already similar to the mammalian high-mannose core unit Man $_{5-6}$ GlcNAc$_{2}$ (108). Moreover, genetically modified glyco-engineered $P$. pastoris strains have been generated which 
produce humanized glycosylation patterns (109-113). The therapeutic IgG antibodies produced in glyco-engineered yeast achieved results that were comparable to its counterpart Trastuzumab that has been produced in mammalian cells (114). Unlike IgGs produced in wildtype yeast, those produced in glyco-engineered yeasts were able to mediate antibody-mediated effector functions. Production processes employing glyco-engineered yeasts are currently optimized for commercial antibody production (115) as well as for high throughput screening (116).

\section{FILAMENTOUS FUNGI}

Filamentous fungi of the genera Trichoderma and Aspergillus have the capacity to secrete large amounts of proteins and metabolites into the medium (117). They are widely used in the food and biotechnological industry, for example $A$. niger for citric acid production. Moreover, A. niger (subgenus A. awamori) and Aspergillus oryzae gained obtained GRAS status. Two promoters are typically used for the expression of antibodies in fungi: the glucoamylase promoter (glaA) (118) and the endoxylanase A promoter (exlA) (119). Antibody chains are usually fused to the aminoterminus of glucoamylase in Aspergillus and cellobiohydrolase I in Trichoderma spec., respectively, in order to obtain optimal secretion (120). Moreover, protease cleavage sites like KexB are introduced to release the antibody from glucoamylase before secretion (118). Yields of up to $1.2 \mathrm{~g} / \mathrm{L}$ IgG were achieved in $A$. niger when both antibody chains were fused to glycoamylase. In Trichoderma reesei, $150 \mathrm{mg} / \mathrm{L}$ of a Fab fragment was obtained when both chains were fused with cellobiohydrolase I increasing yields 100-fold higher than with its natural signal peptide (121). A. awamori was used for the production of several scFvs, llama VHHs and antibody enzyme fusion proteins $(117,119,122)$. A yield of $73.8 \mathrm{mg} / \mathrm{L}$ of an antiEGFR-VHH was achieved in A. oryzae by using a Taka-amylase A signal sequence and 28 amino acids from the aminoterminal region of Rhizopus oryzae lipase (123).

Fungal proteases can result in protein degradation which was addressed by deletion mutants. Chrysosporium lucknowense C1 contains a triple protease deletion (Delta-alp1, Delta-pep4, Deltaalp2) and was successfully used in small-scale productions for screening as well as in high scale bioreactor productions (124).

\section{PROTOZOA}

Recently, the eukaryotic parasite Leishmania tarentolae has been explored as an expression system for different recombinant proteins $(125,126)$. One major advantage of this expression system is the mammalian-like glycosylation pattern: this protozoa is able to perform $\mathrm{O}$-glycosylation as well as $\mathrm{N}$-glycosylation, which is highly conserved in mammalians (127). Consequently, L. tarentolae has been begun to be used for the production of recombinant antibodies: analysis of different signal peptides lead to a protein yield of $2-6 \mathrm{mg} / \mathrm{L}$ purified $\mathrm{scFv}$ (128).

\section{INSECT CELLS}

Insect cells represent a very versatile eukaryotic expression system. They can be efficiently transfected with insect-specific viruses from the family of Baculoviridae, particularly the Autographa californica nuclear polyhedrosis virus (AcNPV). Baculoviruses are highly species-specific and are considered as safe for humans, mammalians and plants. Infection of human hepatocytes and mammalian cell lines including stable transduction has been demonstrated in cell culture without evidence of viral replication or gene expression under the control of baculoviral promoters $(129,130)$. Non-essential baculovirus genes involved in the viral life cycle, like Polyhedrin, P10, or Basic can be replaced by heterologous genes. The flexible viral envelop allows packaging of large heterologous gene sequences of more than $20 \mathrm{~kb}$. Heterologous genes under the control of the strong polyhedron promoter are expressed at levels ranging from 0.1 to $50 \%$ of the total insect cell protein. Baculoviral protein expression is normally performed in insect cell lines like Sf-9 and Sf-21 of Spodoptera frugiperda, DS2 cells of Drosophila melanogaster, or High Five cells (BTI-TN-5B14) of Trichopulsia ni. High Five cells have certain advantages over Sf-9 cells for recombinant protein expression because they secrete up to 25-fold higher protein levels (131), have a more rapid doubling time, allow quick adaptation to serum-free medium and grow in suspension culture. In contrast, Sf- 9 and Sf- 21 cells are recommended for producing high-titer viral stocks due to higher transfection efficiency. Recombinant protein production can be performed in small-scale using plates or shake flasks as well as in large scale using Spinner flasks or bioreactors. Important parameters for optimizing baculoviral protein production are multiplicity of infection (m.o.i.), production length (usually up to $96 \mathrm{~h}$ ), addition of protease inhibitors due to the release of viral proteases, temperature (usually $25-30^{\circ} \mathrm{C}$ ), and media $\mathrm{pH}(\mathrm{pH} 6.0-6.4$ ).

Secreted monomeric anti-phOx scFv were obtained at levels of up to $32 \mathrm{mg} / \mathrm{L}$ in a 6-L bioreactor with $10^{9}$ cells per liter after $72 \mathrm{~h}$ with an m.o.i. of 1 (132). Production yields of 6-18 mg/L have been achieved for various IgGs (133). Immunoglobulins produced in High Five cells showed mammalian-like terminal galactosyl residues $\beta(1,4)$-linked to the biantennary GlcNAc residues. In contrast, the absence of sialylation, the formation of paucimannosidic structures and the presence of potentially allergenic $\alpha(1,3)$ fucose linkages are different to mammalian glycosylation (134). Nevertheless, IgGs produced in insect cells were able to mediate effector functions like complement binding $(135,136)$ and ADCC (137). Insect cell protein expression was improved using protease deficient baculovirus strains or cell lines with additional glycosyltransferase gene modifications to obtain glycosylation patterns comparable to mammalian cell lines (138-141).

Expression of IgGs in insect cells under control of the strong Polyhedron promoter resulted in an extensive aggregation, probably caused by overloading the cellular folding and post-translational processing apparatus (142).

Overexpression of the ER resident chaperone binding protein (BiP) significantly enhanced levels of soluble and secreted IgGs in T. ni cells (143). Enhanced secretion of IgGs was also achieved by coexpression of protein disulfide isomerase (PDI) or the human cytosolic chaperone hsp70 in T. ni cells (138).

Due to strong usage of the cellular metabolism during baculoviral protein expression a high diversity in the post-translational modification was observed. Alternatively to baculoviral expression, insect cells can also be transfected with expression plasmids in a transient or stable manner. Here, usually Schneider 2 (S2) cells of D. melanogaster are used. Secretory production requires a signal sequence like the honeybee melittin leader. Stable transfection 
of Drosophila cell lines with monomeric and dimeric antibody fragments resulted in yields of up to $25 \mu \mathrm{g} / \mathrm{mL}$ (144).

Immunoglobulin $\mathrm{G}$ production using the baculovirus expression system demonstrated IgG effector function such as complement binding $(135,136) .10 \mu \mathrm{g} / \mathrm{mL}$ of anti-Rhesus $\mathrm{D}$ antibody produced in Sf-9 cells mediated lysis of $\mathrm{Rh}+$ red blood cells by $\operatorname{ADCC}(137)$.

\section{MAMMALIAN CELLS}

Today, $60-70 \%$ of all recombinant protein pharmaceuticals and 95\% of the currently approved therapeutic antibodies are still produced in mammalian cell lines despite relatively high production costs and difficult in handling. However, the advanced mammalian folding, secretion and post-translational apparatus is capable of producing antibodies indistinguishable from those in the human body with least concerns for immunogenic modifications. Moreover, it is also highly efficient for secretion of large and complex IgGs and in combination with the folding and post-translational control it results in high product quality which reduces efforts and costs in the subsequent and more expensive downstream processing steps. The risks of contamination by pathogens or bovine spongiform encephalopathy (TSE/BSE) agents have been eliminated by well-documented Good Manufacturing Practice (GMP) compliant designer cell substrates and chemical defined media without the need of supplementing animal serum components (145). In 2004, mammalian cell culture technology reached production levels of approximately $5 \mathrm{~g} / \mathrm{L}$ IgGs in Chinese hamster ovary (CHO) cells (146). Today, industrial IgG production levels often exceed $12 \mathrm{~g} / \mathrm{L}$ as the result of a steadily ongoing progress in mammalian cell culture technology, which is mainly due to improved high producer cell lines, optimized production media, and prolonged production processes at high-cell densities. The highest reported IgG production titer we found was obtained in the human embryonic retinal cell line Per.C6 [Crucell, Leiden, Netherlands, (147)] with $27 \mathrm{~g} / \mathrm{L}$. Generally, the productivity of recombinant mammalian cell lines increased from initially $10 \mathrm{pg}$ antibody per cell per day (pcd) in 1986 to about 90 pcd in 2004. Today, the antibody production levels only rarely exceed 100 pcd because higher cellular productivity usually corresponds to lower maximum cell densities in the production process. Producer cell lines have also been genetically engineered regarding product homogeneity, improved metabolism, reduced apoptosis, and inducible cell cycle arrest $(148,149)$ which allows prolonged production times for almost 3 weeks at high-cell viability and cell densities.

Chinese hamster ovary $(\mathrm{CHO})$ cells are the most common cells applied in the commercial production of biopharmaceuticals. This cell line isolated in the 1950s gave rise to a range of genetically different progeny, such as K1-, DukX B11-, DG44cell lines and others which differ in protein product quality and achievable yield. In addition, Per.C6 cells, mouse myeloma NS0 cells, baby hamster kidney (BHK) cells and the human embryonic kidney cell line HEK293 received regulatory approval for recombinant protein production. Although glycosylation patterns of mammalian glycoproteins are very similar to that in humans (150), even small differences can influence pharmacokinetics and effector functions of antibodies. Alternative designer cell lines with improved glycosylation patterns have been generated, for example human neuronal precursor cell line AGE1.HN (Probiogen, Berlin, Germany) supporting specific and complex glycostructures for the production of antibodies which require specific posttranslational modifications or suffer from instability or susceptibility for proteolysis (151). CHO cell variant Lec13 (Glycotope) also produces human IgG1 with $N$-Linked glycans lacking fucose which improves on Fc-gammaRIII binding and ADCC (152).

\section{Stable production of antibodies in mammalian cells}

The generation of stable master cell lines is a prerequisite for GMP compliant IgG production in the therapeutic sector in order to guarantee long term production stability. Here, the antibody gene expression cassettes have to be stably integrated into the host cell genome.

Strong promoters like the immediate early cytomegalovirus (CMV) or the cellular elongation factor (EF) 1-alpha promoter and polyadenylation sites from the simian virus (SV) 40 or the bovine growth hormone (BGH) for improved mRNA stability and translation efficiency are usually implemented into the expression vector. Furthermore, splicing of mRNA is known to promote mRNA packaging and transfer into the cytosol in order to stabilize and enhance gene expression as well as to reduce silencing of heterologous transgenes $(153,154)$. For IgG expression, two different genes must be stably transfected into one cell clone, either by cotransfection or by using bicistronic expression vectors. Bicistronic vectors employing internal ribosomal entry sites (IRES) allow the translation of two or more cistrons from the same transcript (155). The encephalomyelitis virus (ECMV) IRES has shown the highest efficiency in various mammalian cell lines. Mutated IRES derivatives allow the control of translation efficiency in relation to the cap-dependent cistron. The ratio between light and heavy chain has great impact on the secretion level of functional IgGs (156). The long term stability of ECMV IRES containing bicistronic constructs has been demonstrated even in the absence of selection pressure over months (157).

There are different methods to enhance antibody expression by increasing the number of antibody gene copies in the genome through gene amplification. The two major systems on the market are based on dihydrofolate reductase (DHFR) or glutamyl synthetase (GS) selection. Yield and functionality of an IgG1 produced in $d h \mathrm{fr}^{-} \mathrm{CHO}$ and GS-NSO are equivalent (158) and reached $1.8 \mathrm{~g} / \mathrm{L}$ in GS-NS0 cells (159). However, gene amplification also causes genetic instability, and after removing the selection pressure the yield of antibodies can be reduced again. Moreover, high producer cell lines often contain only a few copies of the antibody genes. For example, up to $2.7 \mathrm{~g} / \mathrm{L}$ final antibody concentration were obtained from NS0 cells containing three vector copies per cell (160). Other factors than the number of gene copies play an important role to achieve high production levels of antibodies. Therefore, industrial antibody expression platforms employ efficient screening systems in order to isolate the best of the high producers. However, there are also strategies to facilitate the isolation of high producer clones (161). To overcome negative effects of the integration site, protective cis-regulatory elements include insulators, boundary elements, scaffold/matrix attachment regions (S/MARs) (162), chromatin opening elements 
(163), and antirepressor elements (164) were introduced into the vector which reduced the influence of heterochromatin and stabilize transgene expression $(165,166)$. Silencing can be blocked by inhibition of histone deacetylation using butyrate (167) which could enhance the protein expression levels of the cells (168) but can also induce apoptosis.

Recombination enzymes, like bacteriophage P1 Cre recombinase, lambda phage integrase, or yeast Flp recombinase can efficiently catalyze the site specific integration into defined chromosomal recombination exchange cassettes which have been introduced into producer cell lines $(169,170)$. The 2A/furin technology allows expression of both IgG chains as a single gene due to post-translational auto-cleavage of the viral protease $2 \mathrm{~A}$ encoded by the linker and subsequent processing by the Golgi protease furin $(171,172)$.

\section{Transient production of antibodies in mammalian cells}

The generation of high producer cell lines has been dramatically improved and accelerated $(161,173)$, however it is still too expensive, time-consuming and laborious for research applications, or if large numbers of individual antibodies have to be produced. Here, transient and semi-stable mammalian antibody expression is much more suitable because it allows fast and parallelized production without any need to generate producer cell lines (174). Moreover, transient mammalian antibody production can be scaled up by employing batch or fed-batch bioreactor processes to more than $150 \mathrm{~L}$ production volumes (175). Therefore, transient antibody production is suitable for small-scale production in antibody screening (176), but also capable to generate grams of antibodies (177-179).

The human embryonic kidney (HEK) 293 cell lines have been widely used for transient protein expression because they can be very efficiently transfected with plasmid DNA. Some derivatives were further transformed either with the simian virus 40 (SV40) large T antigen, termed HEK293T, or with the Epstein Barr virus (EBV) nuclear antigen 1 (EBNA1), termed HEK293E, in order to mediate semi-stable episomal propagation of vectors containing an origin of replication (ori) of SV40 or EBV, respectively. Transient transfection of plasmid DNA in HEK293 cells can also be performed in large scale by calcium phosphate transfection (180), cationic liposomes, and polymers like polyethyleneimine (PEI) $(181,182)$.

Recently, transient production of IgG-like scFv-Fc antibodies in the HEK293-6E cell line, a genetically modified variant with a truncated version of EBNA1 growing in suspension and chemically defined serum-free medium $(183,184)$, achieved volumetric yields of up to $0.6 \mathrm{~g} / \mathrm{L}$ by simple shake flask cultivation. Improved production media, fed-batch supplementation, and well-controlled bioreactor processes allow higher cell densities and prolonged production time, both enhancing the yield. Backliwal and colleagues (177) combined optimized PEI-based transfection at high-cell densities with the coexpression of cell cycle regulators p18 and $\mathrm{p} 21$, acidic fibroblast growth factor, valproic acid supplementation, consequent maintenance at high-cell densities of cells/milliliter and up-scaling to $2 \mathrm{~L}$ and achieved production levels of more than $1 \mathrm{~g}$ IgG within 2 weeks after transient transfection.

\section{TRANSGENIC ORGANISIMS TRANSGENIC PLANTS}

The development of transgenic plants for the expression of recombinant antibodies is becoming interesting, especially when high amounts are required. Up-scaling of this production system can be achieved more easily compared to other systems such as mammalian cell culture, where up-scaling of the fermentation process leads to increasing production costs. In theory, the costs of an IgA expressed in plants are only $1-10 \%$ compared to the expression in hybridoma cells (185).

The generation of genetically modified dicotyledonous plants is mainly done by the transfer of the expression cassette of the transgene with the help of Agrobacterium tumefaciens. In principle, the gene of interest is cloned into the T-DNA of a binary plasmid (186, 187 ) which is flanked by two 25 bp imperfect repeats. In most cases, the expression of the transgene is under the control of one or two (188) copies of the constitutive cauliflower mosaic virus (CaMV). In addition, a selection marker is located on the T-DNA and transferred into the host genome for effective screening of successfully transformed plants. After integration of the T-DNA into the host genome by non-homologous recombination complete plants can be regenerated from transformed pieces of the plant [RB (189)]. As this procedure requires several months of transformation and special regeneration protocols, transient expression systems have been developed which allow time saving production of recombinant proteins: McCormick and colleagues designed a tobacco mosaic virus (TMV) based vector for the secretory expression of different scFvs for the treatment of non-Hodgkin's lymphoma (190). Expression yields in Nicotiana benthamiana were up to 100 $800 \mu \mathrm{g} / \mathrm{mL}$ in the crude secretory extract. Same technique has been applied for the expression of idiotype-scFvs for personalized vaccination of follicular B-cell lymphoma patients in a phase I clinical study (191). In this study, nearly half of the treated patients developed an antigen specific immune response despite differences in glycosylation pattern.

Differences in the glycosylation pattern between mammalia and plants are one of the main obstacles researchers have to overcome when developing therapeutic antibodies expressed in plants. Although plants are able to perform complex glycosylation, differences in glycosylation patterns, in particular $\beta 1,2$-xylose and $\alpha 1,3$ fucose, can lead to immunogenicity of the therapeutic proteins (192-194). Therefore, different strategies have been developed to express recombinant proteins with a more mammalian-like glycosylation pattern. The first one is the retention of the protein in the endoplasmic reticulum (eR) as eR-associated $\mathrm{N}$-glycosylation leads to the generation of oligomannose-type $N$-glycans which are identical in plants and mammalians $(192,195)$. One side effect of this localization is the accumulation to higher levels in the eR $(196,197)$. A second approach for the expression of proteins with mammalian-like glycosylation patterns is the usage of glycoengineered plants. In most cases, RNA interference (RNAi) is used for the down-regulation of endogenous beta1,2-xylosyltransferase and alpha1,3-fucosyltransferase leading to a reduction of the xylosylated and core-fucosylated $N$-glycans (198-200). A second type of glyco-engineering in plants is the coexpression of genes which facilitates the expression of human-like $N$-glycans (201) or even 
the in planta protein sialylation by the coexpression of six mammalian genes (202). An increasing effort has been put into the adaptation of $\mathrm{N}$-glycosylation, but there are also some efforts in the engineering of sialylated mucin-type $O$-glycans to achieve the most human-like glycosylation patterns (203, 204). Alternatively, non-glycosylated antibodies which mediate protection against an inhalation anthrax spore challenge in non-human primates showed an improvement of the half-life in serum (205). Rodriguez and colleagues showed that the aglycosylated form of Nimotuzumab (currently in a phase II clinical study in the USA and Canada) produced in tobacco shares the in vitro and in vivo properties as well as the antitumor effect in nude mice with the glycosylated form (206).

Transient expression of an antibody in plants can be achieved using viral vectors. The main problem with this approach is the low infectivity with these vectors. Therefore, the more efficient transfer of $A$. tumefaciens was combined with the speed and high expression rate of plant RNA viruses (207). This system has been used for the expression of monoclonal antibodies in Nicotiana benthamiana with yields up to $0.5 \mathrm{~g} / \mathrm{kg}$ fresh weight (208).

In principle, most plantibodies are expressed in tobacco $(N$. tabacum or N. benthamiana), but there are also production systems in Lemna minor (duckweed) (209-211), rice cell culture (212), Arabidopsis thaliana seeds (213, 214), Medicago sativa (alfalfa) (215), lettuce (216), and maize (217). HIV-1 neutralizing antibody $2 \mathrm{G} 12$ was expressed in the endosperm of maize and showed similar or even better neutralizing properties as its CHO-derived counterpart (218).

Besides the transfection or transformation of whole plants or at least organs, monoclonal BY-2 tobacco cell lines that grow in suspension have been developed (219). Flow cytometric analysis has been used to enrich cells expressing a fluorescent marker which was located on the same T-DNA with the antibody gene. Using this method for the enrichment of high expressing cells, production could be increased up to 13 -fold and was shown to be stable for 10-12 months.

Much effort has been set into the establishment and development of plants producing antibodies for therapy, but so far none of these products has appeared on the market, despite of the estimated dramatic reduction of production costs (220). Nevertheless, at least two plant derived antibodies have been used in clinical trials: CaroRX was developed by Planet Biotechnology (Hayward, CA, USA) and is expressed in transgenic tobacco (221). This antibody binds to the streptococcal antigen I/II of $S$. mutans, the major causative agent of bacterial tooth decay and prevents the attachment of $S$. mutans to tooth enamel. CaroRX has entered clinical phase II $(222,223)$. A second plant-made antiidiotype antibody against non-Hodgkin-lymphoma (NHL) which was successfully tested in clinical phase I study has been mentioned above $(191,224)$.

\section{TRANSGENIC ANIMALS}

In recent years the idea of expressing human antibodies in transgenic animals has increased. On the one hand the humanization of antibodies for therapeutics derived from hybridoma technology is still a laborious and time-consuming procedure which often requires the generation and characterization of a set of different humanized versions of the antibody. On the other hand the mouse or rat derived antibodies may elicit an immune response in patients $(225,226)$. One method for the generation of fully human binders is the antibody phage display technology (21).

Beside this, several researchers developed transgenic animals for the production and expression of human monoclonal and polyclonal antibodies: therefore, human antibodies have mostly been expressed in the milk of transgenic mice (227-230), goats (231), or even in eggs of transgenic chickens (232).

The first step toward the generation of human antibodies in animals by immunization was the transfer of a human minilocus containing unrearranged immunoglobulin variable, diversity, and joining elements linked to a human $\mu$-chain into mice (233). In this study, approximately $4 \%$ of the extracted B-lymphocytes expressed human antibodies. The immunization of larger animals containing human chromosomal immunoglobulin loci would enable the production of even larger amounts of antibodies. Therefore, transgenic cattle were developed by the transfer of a human artificial chromosome vector containing the entire unrearranged sequences of the human immunoglobulin heavy and lambda light chain loci (234). For the improvement of the human antibody proportion and for safety reasons regarding the potential risk of BSE, the bovine immunoglobulin $\mu$ heavy chain locus and the bovine prion protein have been knocked out $(235,236)$. Finally, transgenic cattle carrying human immunoglobulin heavy and kappa-light chain loci have been used for immunization with anthrax protective antigen. The resulting polyclonal antibody mixture consisted of entirely human and chimeric immunoglobulins that showed high activity and were protective in an in vivo mouse challenge models (237). Rabbits and cattle were used for expression of a bispecific scFv targeting the melanoma-associated proteoglycan and the human CD28 molecule on T cells (238). The usage of different animals as a source for the generation of human polyclonal sera has already been initiated: the immunoglobulin gene loci have been knocked out in livestock such as pigs or rabbits (239-241). For a review of approaches for the generation of transgenic animals expressing polyclonal human antibodies see Houdebine (242).

Much of the energy in transgenic production has been set on the development of humanized mice or rats. The well established property of generating hybridoma cells from these species facilitates a streamlined approach for the generation of a cell line which stably expresses monoclonal antibodies $(17,243,244)$. Using humanized mice, an anti-HIV-1 gp140 antibody was identified, but in contrast the low number of antigen specific hybridomas occurring during the generation of the clones has been observed (245). Therefore, the usage of humanized rats has been suggested to circumvent these problems and first antibodies have been developed with sub-nanomolar affinities using the so called OmniRat (246).

\section{CONCLUDING REMARKS}

Today, mammalian cell lines represent the most widely used expression system for the production of recombinant antibodies. Several other hosts are being developed which are even able to produce antibodies with human-like glycosylation patterns. In addition to this, there are several applications where the glycosylation 
Table 1 | Production of recombinant antibodies by host.

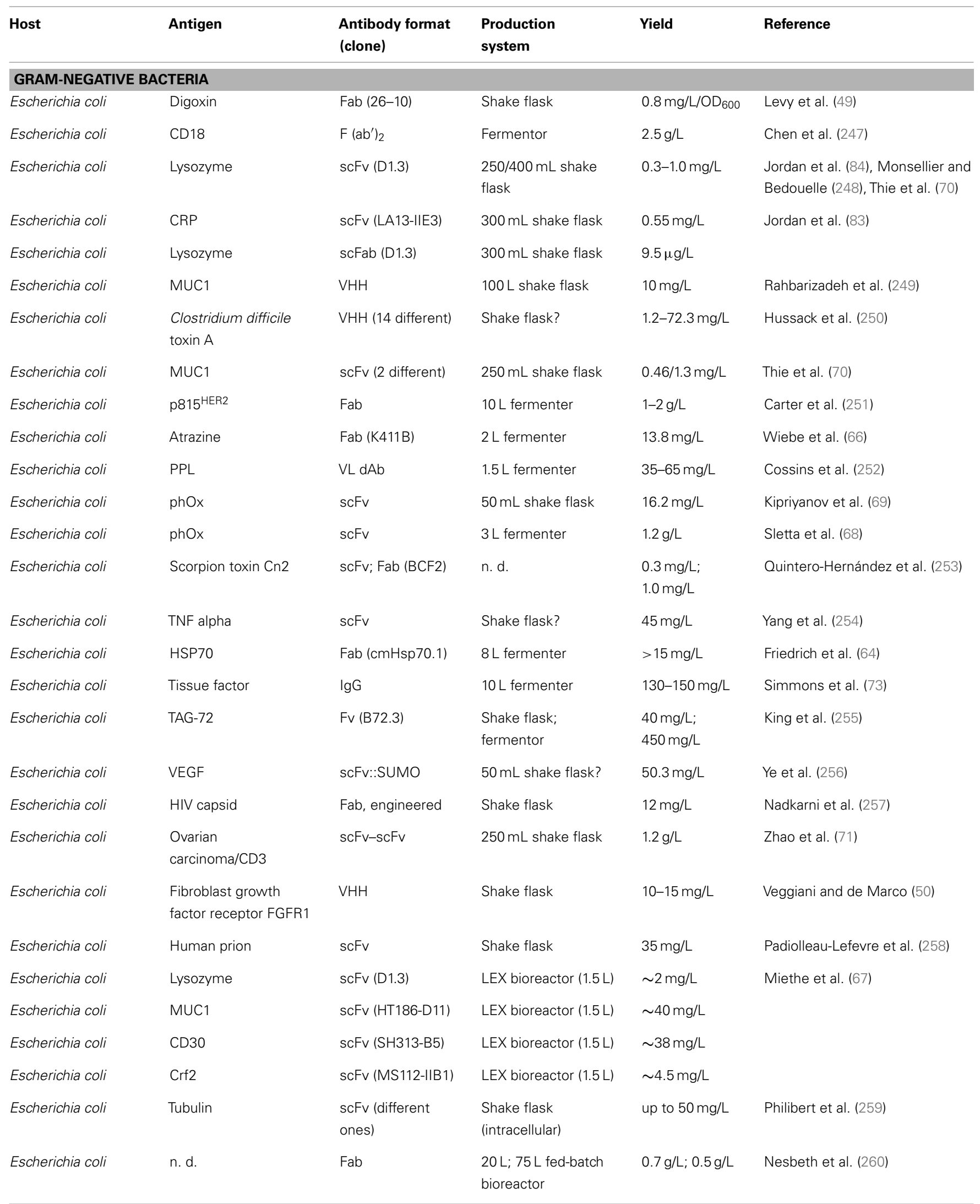


Table 1 | Continued

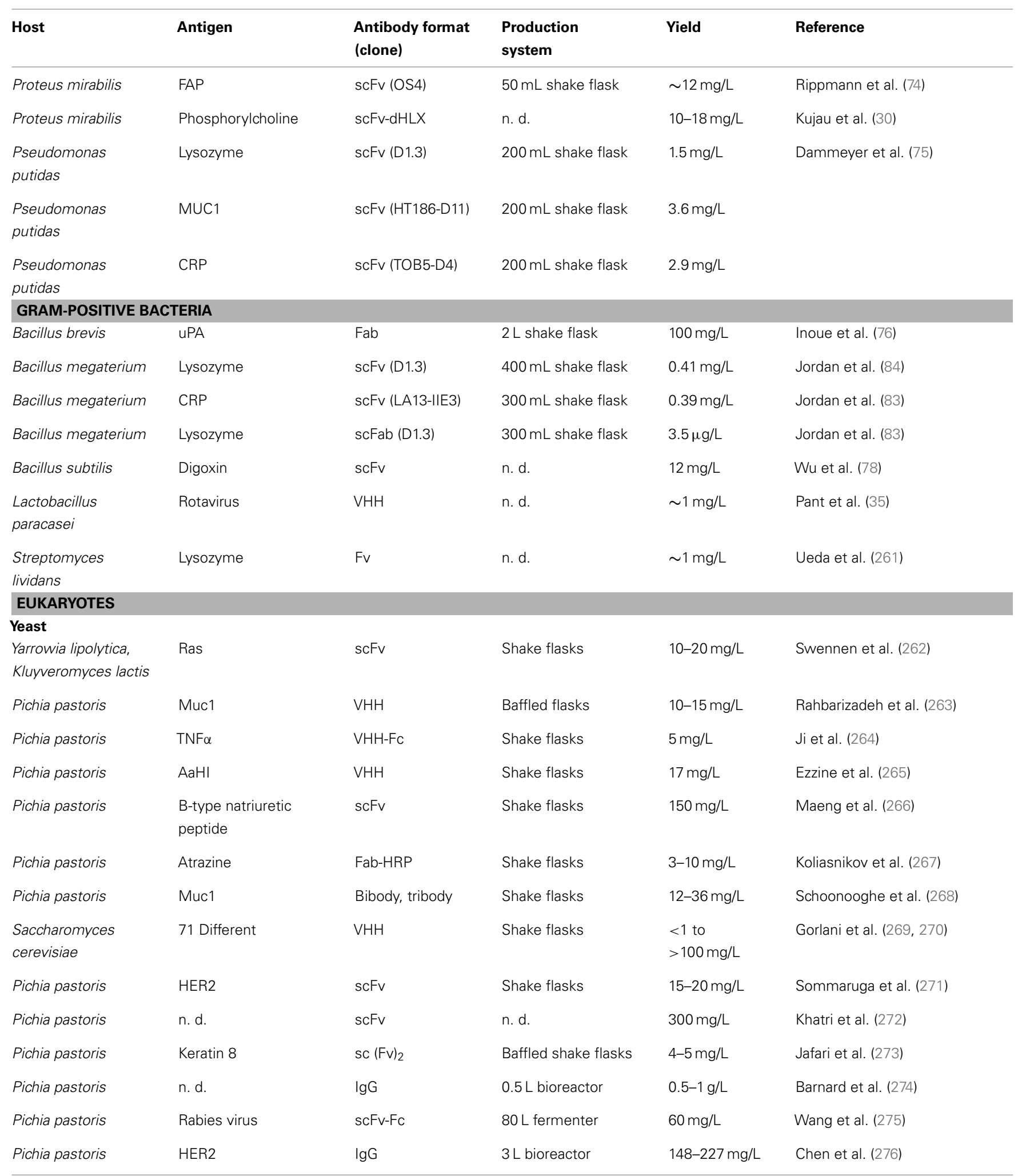


Table 1 | Continued

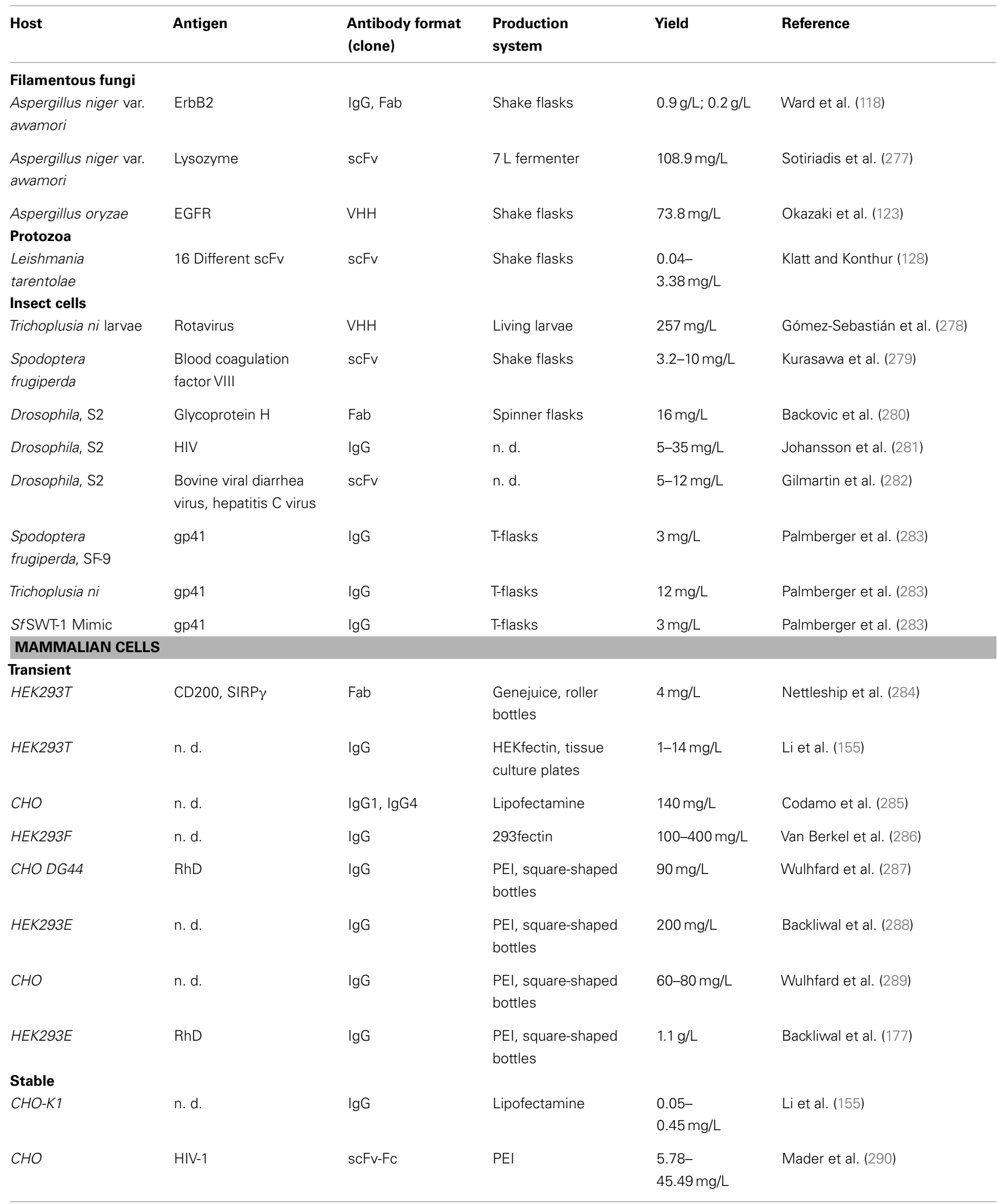


Table 1 | Continued

\begin{tabular}{|c|c|c|c|c|c|}
\hline Host & Antigen & $\begin{array}{l}\text { Antibody format } \\
\text { (clone) }\end{array}$ & $\begin{array}{l}\text { Production } \\
\text { system }\end{array}$ & Yield & Reference \\
\hline $\mathrm{CHO}$ & n. d. & $\lg G$ & Electroporation & $4 \mathrm{~g} / \mathrm{L}$ & Kober et al. (291) \\
\hline NSO & n. d. & $\lg G$ & $\begin{array}{l}5 \mathrm{~L} \text { bioreactor, } \\
\text { fed-batch }\end{array}$ & $800 \mathrm{mg} / \mathrm{L}$ & Spens and Häggström (292) \\
\hline per.C6 & n. d. & $\lg G$ & Roller bottle culture & $50-100 \mathrm{mg} / \mathrm{L}$ & Jones et al. (147) \\
\hline per.C6 & n. d. & $\lg M$ & Shake flasks & $0.5-2 \mathrm{~g} / \mathrm{L}$ & Tchoudakova et al. (294) \\
\hline $\begin{array}{l}\text { Chlamydomonas } \\
\text { reinhardtii }\end{array}$ & CD22 & $\begin{array}{l}\text { Immunotoxin, } \\
\text { exotoxin A }\end{array}$ & $\begin{array}{l}\text { Particle } \\
\text { bombardement }\end{array}$ & $\begin{array}{l}0.2-0.4 \% \text { of } \\
\text { chloroplasts }\end{array}$ & Tran et al. (297) \\
\hline Nicotiana tabacum & BoNT/A & scFv & $\begin{array}{l}\text { Agrobacterium } \\
\text { tumefaciens }\end{array}$ & $20-40 \mathrm{mg} / \mathrm{kg}$ & Almquist et al. (298) \\
\hline $\begin{array}{l}\text { Nicotiana } \\
\text { benthamiana }\end{array}$ & HIV & $\lg G$ & CPMV & $105.1 \mathrm{mg} / \mathrm{kg}$ & Sainsbury et al. (299) \\
\hline Nicotiana tabacum & $\mathrm{HCC}$ & scFv-RNase & $\begin{array}{l}\text { Agrobacterium } \\
\text { tumefaciens }\end{array}$ & $0.75-1.99 \mu \mathrm{g} / \mathrm{g}$ & Cui et al. (300) \\
\hline Mouse & HER2 & $\mathrm{scFv}-\mathrm{Fc}$ & Milk & $\sim 120 \mathrm{ng} / \mathrm{mL}$ & Yuskevich et al. (305) \\
\hline Chicken & CD2, prion peptide & Chimeric lgG & Egg white & $<150 \mu \mathrm{g} / \mathrm{mL}$ & Kamihira et al. (306) \\
\hline
\end{tabular}

AaHI, toxin class I of Androctonus australis hector scorpion venom; BoNT/A, Bolutinum toxin serotype A; CPMV, cowpea mosaic virus; FAP, fibroblast activation protein alpha; HCC, hepatocellular carcinoma; phOx, 2-phenyl-oxazoline-5on; PEl, polyethyleneimine; PPL, peptostreptococcal protein L; RhD, rhesus factor D; uPA, urokinase type plasminogen activator.

pattern does not play a critical role, such as for in vitro diagnostics or in research. Therefore, bacteria, yeasts, filamentous fungi, and insect cells can be employed in order to lower the production costs of these products. In principle, transgenic plants and animals have the highest potential for up-scaling processes to theoretically unlimited production amounts. An overview of recombinant antibodies produced in different hosts is shown in Table 1. There, however, it must be discriminated between the yield of functional antibodies after purification and the total yield.

Antibody phage display is now a widespread method for the development of antibody fragments such as scFv or Fab. The expression host used in this technology is E. coli which is known to be the best genetically examined organism providing a large set of molecular biological tools for genetical engineering. Consequently, both antibody generation and production can be performed without changing the production system. Using high-cell density fermentation, the yield can be up to $1-2 \mathrm{~g} / \mathrm{L}$ depending on the individual antibody fragment. Antibody fragments expressed in E. coli are mainly secreted into the periplasm and have to be extracted from there. Gram-positive bacteria lack the outer membrane and are well suited for biotechnological processes due to their powerful secretion apparatus which allow easy purification directly from the cultivation supernatant. However, antibody production systems employing Gram-positive bacteria are still in the 
developmental stage. However, larger antibody formats are very difficult to express in bacteria, if they can be expressed at all. Furthermore, the lack of a glycosylation apparatus limits their use, if effector functions are needed.

Yeasts, as an eukaryotic organism, has the capacity to perform post-translational modifications. In addition, they can be used even in high throughput processes and glyco-engineering enables the expression of recombinant proteins with human-like glycosylation. Nevertheless, the production of full-size immunoglobulins remains a challenge. Compared to yeasts, filamentous fungi are more difficult for the generation of transformed clones, but they have a long tradition for the usage in biotechnology and they have partially been used for the expression of IgGs. In contrast, the development of protozoa as an expression system for recombinant proteins and antibodies has just been started and is still in a developmental stage. However, the mammalian-like glycosylation pattern presents them a promising candidate for further exploitation.

Insect cells contain a better suited protein folding and secretion apparatus than prokaryotes. Their high robustness combined with less sophisticated requirements for fermentation provide some advantages compared to mammalian cells. However, the development of stable insect cell lines and process technology is not developed as far. Consequently, mammalian cell lines are most widely used for the production of therapeutic antibodies as they

\section{REFERENCES}

1. Colwill K, Renewable Protein Binder Working Group, Gräslund S. A roadmap to generate renewable protein binders to the human proteome. Nat Methods (2011) 8:551-8. doi:10.1038/nmeth.1607

2. Mehan MR, Ostroff R, Wilcox SK, Steele F, Schneider D, Jarvis TC, et al. Highly multiplexed proteomic platform for biomarker discovery, diagnostics, and therapeutics. Adv Exp Med Biol (2013) 735: 283-300.

3. Foudeh AM, Fatanat Didar T, Veres T, Tabrizian M. Microfluidic designs and techniques using labon-a-chip devices for pathogen detection for point-of-care diagnostics. Lab Chip (2012) 12:324966. doi:10.1039/c2lc40630f

4. Uttamchandani M, Neo JL, Ong BNZ, Moochhala S. Applications of microarrays in pathogen detection and biodefence. Trends Biotechnol (2009) 27:53-61. doi: 10.1016/j.tibtech.2008.09.004

5. Van Breedam W, Costers S, Vanhee M, Gagnon CA, RodríguezGómez IM, Geldhof $M$, et al. Porcine reproductive and respiratory syndrome virus (PRRSV)specific mAbs: supporting diagnostics and providing new insights into the antigenic properties of the virus. Vet Immunol Immunopathol
(2011) 141:246-57. doi:10.1016/j. vetimm.2011.03.008

6. Van Hoeven KH, Dale C, Foster P, Body B. Comparison of three enzyme-linked immunosorbent assays for detection of immunoglobulin $g$ antibodies to tetanus toxoid with reference standards and the impact on clinical practice. Clin Vaccine Immunol (2008) 15:1751-4. doi:10.1128/ CVI.00254-08

7. Zasada AA, Rastawicki W, Smietanska K, Rokosz N, Jagielski M. Comparison of seven commercial enzyme-linked immunosorbent assays for the detection of anti-diphtheria toxin antibodies. Eur J Clin Microbiol Infect Dis (2013) 32:891-7. doi:10.1007/ s10096-013-1823-y

8. Dübel S editor. Handbook of Therapeutic Antibodies. Weinheim: Wiley-VCH (2008). doi:10.1002/ 9783527619740

9. Reichert JM. Which are the antibodies to watch in 2013? MAbs (2013) 5:1-4. doi:10.4161/mabs. 22976

10. Eisenberg SA. Biologic therapy. J Infus Nurs (2012) 35:301-13. doi: 10.1097/NAN.0b013e31826579aa

11. Dimitrov DS. Therapeutic proteins. In: Voynov V, Caravella JA editors. Therapeutic Proteins, Methods in Molecular Biology.

provide a sophisticated folding and secretion apparatus as well as human-like glycosylation. For the production of high levels of recombinant antibodies high technical efforts are needed leading to relatively high costs. The maximum reported yield of functional IgG was $5 \mathrm{~g} / \mathrm{L}$ which cannot be achieved using other expression systems so far, but up-scaling of the production does not lead to a high reduction of the production costs.

For an efficient reduction of production costs, transgenic plants can be used as they represent a highly scalable expression system; cultivation can be easily expanded without a gross increase in costs. In contrast, the generation of transgenic plants remains very complex and difficult. The most important obstacle of transgenic plants is the downstream processing as tons of plant material may have to be processed. However, antibody production in milk or eggs of animals would also be highly scalable and permits easy downstream processing. Several livestock animal species have been developed for the expression of recombinant proteins, but generation of transgenic animals also is very laborious. An interesting approach is the combination of human transgenic animals with hybridoma technology for the development of human antibodies.

In principle, there is no "universal" production system which can guarantee high yields of recombinant antibody, particularly as every antibody-based molecule itself will cause its own issues in terms of expression.

Clifton, NJ: Humana Press (2012) p. 1-26.

12. Wilde $\mathrm{H}$, Thipkong $\mathrm{P}$, Sitprija V, Chaiyabutr N. Heterologous antisera and antivenins are essential biologicals: perspectives on a worldwide crisis. Ann Intern Med (1996) 125:233-6. doi:10.7326/0003-4819-125-3199608010-00012

13. Köhler G, Milstein C. Continuous cultures of fused cells secreting antibody of predefined specificity. Nature (1975) 256:495-7. doi:10.1038/256495a0

14. Reichert JM. Antibody-based therapeutics to watch in 2011. MAbs (2011) 3:76-99. doi:10.4161/mabs. 3.1.13895

15. Reichert JM. Antibodies to watch in 2010. MAbs (2010) 2:84-100. doi:10.4161/mabs.2.1.10677

16. Nemazee DA, Bürki K. Clonal deletion of $\mathrm{B}$ lymphocytes in a transgenic mouse bearing antiMHC class I antibody genes. Nature (1989) 337:562-6. doi:10. 1038/337562a0

17. Taylor LD, Carmack CE, Schramm SR, Mashayekh R, Higgins KM, Kuo CC, et al. A transgenic mouse that expresses a diversity of human sequence heavy and light chain immunoglobulins. Nucleic Acids Res (1992) 20:6287-95. doi:10. $1093 /$ nar/20.23.6287
18. Breitling F, Dübel S, Seehaus T, Klewinghaus I, Little M. A surface expression vector for antibody screening. Gene (1991) 104:14753. doi:10.1016/0378-1119(91) 90244-6

19. Edwards BM, He M. Evolution of antibodies in vitro by ribosome display. Methods Mol Biol (2012) 907:281-92.

20. Hoogenboom HR. Selecting and screening recombinant antibody libraries. Nat Biotechnol (2005) 23:1105-16. doi:10.1038/nbt1126

21. Schirrmann T, Meyer T, Schütte M, Frenzel A, Hust M. Phage display for the generation of antibodies for proteome research, diagnostics and therapy. Molecules (2011) 16:412-26. doi:10. 3390/molecules 16010412

22. Thom G, Groves M. Ribosome display. Methods Mol Biol (2012) 901:101-16. doi:10.1007/978-161779-931-0_6

23. Edelman GM. Antibody structure and molecular immunology. Science (1973) 180:830-40. doi:10. 1126/science.180.4088.830

24. Bird RE, Hardman KD, Jacobson JW, Johnson S, Kaufman BM, Lee SM, et al. Single-chain antigen-binding proteins. Science (1988) 242:423-6. doi:10.1126/ science. 3140379 
25. Schmiedl A, Breitling F, Winter $\mathrm{CH}$, Queitsch I, Dübel S. Effects of unpaired cysteines on yield, solubility and activity of different recombinant antibody constructs expressed in E. coli. J Immunol Methods (2000) 242:101-14. doi: 10.1016/S0022-1759(00)00243-X

26. Hust M, Jostock T, Menzel C, Voedisch B, Mohr A, Brenneis M, et al. Single chain Fab (scFab) fragment. BMC Biotechnol (2007) 7:14. doi:10.1186/1472-6750-7-14

27. Hudson PJ, Kortt AA. High avidity scFv multimers; diabodies and triabodies. J Immunol Methods (1999) 231:177-89. doi:10.1016/ S0022-1759(99)00157-X

28. Hu S, Shively L, Raubitschek A, Sherman M, Williams LE, Wong JY, et al. Minibody: a novel engineered anti-carcinoembryonic antigen antibody fragment (single-chain Fv-CH3) which exhibits rapid, high-level targeting of xenografts. Cancer Res (1996) 56:3055-61.

29. Kipriyanov SM, Breitling F, Little M, Dübel S. Single-chain antibody streptavidin fusions: tetrameric bifunctional scFv-complexes with biotin binding activity and enhanced affinity to antigen. Hum Antibodies Hybridomas (1995) 6:93-101.

30. Kujau MJ, Hoischen C, Riesenberg D, Gumpert J. Expression and secretion of functional miniantibodies McPC603scFvDhlx in cellwall-less L-form strains of Proteus mirabilis and Escherichia coli: a comparison of the synthesis capacities of L-form strains with an $E$. coli producer strain. Appl Microbiol Biotechnol (1998) 49:51-8. doi:10. 1007/s002530051136

31. Plückthun A, Pack P. New protein engineering approaches to multivalent and bispecific antibody fragments. Immunotechnology (1997) 3:83-105. doi:10.1016/ S1380-2933(97)00067-5

32. Choi BD, Kuan C-T, Cai M, Archer GE, Mitchell DA, Gedeon PC, et al. Systemic administration of a bispecific antibody targeting EGFRvIII successfully treats intracerebral glioma. Proc Natl Acad Sci U S A (2013) 110:270-5. doi:10.1073/pnas.1219817110

33. Fournier P, Schirrmacher V. Bispecific antibodies and trispecific immunocytokines for targeting the immune system against cancer: preparing for the future. BioDrugs (2013) 27:35-53. doi:10. 1007/s40259-012-0008-z

34. Zitron IM, Thakur A, Norkina O, Barger GR, Lum LG, Mittal S.
Targeting and killing of glioblastoma with activated $\mathrm{T}$ cells armed with bispecific antibodies. BMC Cancer (2013) 13:83. doi:10.1186/ 1471-2407-13-83

35. Pant N, Hultberg A, Zhao Y, Svensson L, Pan-Hammarstrom Q, Johansen K, et al. Lactobacilli expressing variable domain of llama heavy-chain antibody fragments (lactobodies) confer protection against rotavirus-induced diarrhea. J Infect Dis (2006) 194:1580-8. doi:10.1086/508747

36. Holt LJ, Herring C, Jespers LS, Woolven BP, Tomlinson IM. Domain antibodies: proteins for therapy. Trends Biotechnol (2003) 21:484-90. doi:10.1016/j.tibtech. 2003.08.007

37. Tang Z, Feng M, Gao W, Phung Y, Chen W, Chaudhary A, et al. A human single-domain antibody elicits potent anti-tumor activity by targeting an epitope in mesothelin close to the cancer cell surface. Mol Cancer Ther (2013) 12:416-26. doi:10.1158/ 1535-7163.MCT-12-0731

38. Powers DB, Amersdorfer P, Poul M, Nielsen UB, Shalaby MR, Adams GP, et al. Expression of single-chain Fv-Fc fusions in Pichia pastoris. J Immunol Methods (2001) 251:123-35. doi:10.1016/ S0022-1759(00)00290-8

39. Wan L, Zhu S, Zhu J, Yang H, Li S, Li Y, et al. Production and characterization of a CD25-specific scFvFc antibody secreted from Pichia pastoris. Appl Microbiol Biotechnol (2012) 97:3855-63. doi:10.1007/ s00253-012-4632-9

40. Ni Y, Chen R. Extracellular recombinant protein production from Escherichia coli. Biotechnol Lett (2009) 31:1661-70. doi:10.1007/ s10529-009-0077-3

41. Schmidt FR. Recombinant expression systems in the pharmaceutical industry. Appl Microbiol Biotechnol (2004) 65:363-72. doi:10.1007/ s00253-004-1656-9

42. Terpe K. Overview of bacterial expression systems for heterologous protein production: from molecular and biochemical fundamentals to commercial systems. Appl Microbiol Biotechnol (2006) 72:211-22. doi:10.1007/ s00253-006-0465-8

43. Skerra A, Plückthun A. Assembly of a functional immunoglobulin Fv fragment in Escherichia coli. Science (1988) 240:1038-41. doi:10. 1126/science. 3285470

44. Better M, Chang CP, Robinson RR, Horwitz AH. Escherichia coli secretion of an active chimeric antibody fragment. Science (1988) 240:1041-3. doi:10.1126/science. 3285471

45. Wörn A, Auf der Maur A, Escher D, Honegger A, Barberis A, Plückthun A. Correlation between in vitro stability and in vivo performance of anti-GCN4 intrabodies as cytoplasmic inhibitors. $\mathrm{J} \mathrm{Biol}$ Chem (2000) 275:2795-803. doi: 10.1074/jbc.275.4.2795

46. Martineau P, Jones P, Winter G. Expression of an antibody fragment at high levels in the bacterial cytoplasm. J Mol Biol (1998) 280:117-27. doi:10.1006/ jmbi.1998.1840

47. Proba K, Wörn A, Honegger A, Plückthun A. Antibody scFv fragments without disulfide bonds made by molecular evolution. J Mol Biol (1998) 275:245-53. doi: 10.1006/jmbi.1997.1457

48. Wörn A, Plückthun A. Mutual stabilization of VL and $\mathrm{VH}$ in single-chain antibody fragments, investigated with mutants engineered for stability. Biochemistry (1998) 37:13120-7. doi:10.1021/ bi980712q

49. Levy R, Weiss R, Chen G, Iverson BL, Georgiou G. Production of correctly folded Fab antibody fragment in the cytoplasm of Escherichia coli trxB gor mutants via the coexpression of molecular chaperones. Protein Expr Purif (2001) 23:338-47. doi:10. 1006/prep.2001.1520

50. Veggiani G, de Marco A. Improved quantitative and qualitative production of single-domain intrabodies mediated by the coexpression of Ervlp sulfhydryl oxidase. Protein Expr Purif (2011) 79:111-4. doi:10.1016/j.pep.2011. 03.005

51. Rusch SL, Kendall DA. Interactions that drive Sec-dependent bacterial protein transport. Biochemistry (2007) 46:9665-73. doi:10.1021/ bi7010064

52. Ge L, Knappik A, Pack P, Freund C, Plückthun A. Expressing Antibodies in Escherichia coli, in: Antibody Engineering. New York: Oxford University Press (1995). p. 229-66.

53. Sletta H, Tøndervik A, Hakvåg S, Aune TEV, Nedal A, Aune R, et al. The presence of N-terminal secretion signal sequences leads to strong stimulation of the total expression levels of three tested medically important proteins during high-cell-density cultivations of Escherichia coli. Appl Environ
Microbiol (2007) 73:906-12. doi: 10.1128/AEM.01804-06

54. Tachibana H, Takekoshi M, Cheng X-J, Nakata Y, Takeuchi T, Ihara S. Bacterial expression of a human monoclonal antibody-alkaline phosphatase conjugate specific for Entamoeba histolytica. Clin Diagn Lab Immunol (2004) 11:216-8.

55. Thie H, Schirrmann T, Paschke M, Dübel S, Hust M. SRP and Sec pathway leader peptides for antibody phage display and antibody fragment production in E. coli. $N$ Biotechnol (2008) 25:49-54. doi: 10.1016/j.nbt.2008.01.001

56. Kirsch M, Zaman M, Meier D, Dübel S, Hust M. Parameters affecting the display of antibodies on phage. J Immunol Methods (2005) 301:173-85. doi:10.1016/j. jim.2005.04.017

57. Ward ES. Antibody engineering using Escherichia coli as host. Adv Pharmacol (1993) 24:1-20. doi:10. 1016/S1054-3589(08)60931-X

58. Hust M, Steinwand M, Al-Halabi L, Helmsing S, Schirrmann T, Dübel S. Improved microtitre plate production of single chain Fv fragments in Escherichia coli. $N$ Biotechnol (2009) 25:424-8. doi: 10.1016/j.nbt.2009.03.004

59. Lauer B, Ottleben I, Jacobsen H-J, Reinard T. Production of a singlechain variable fragment antibody against fumonisin B1. J Agric Food Chem (2005) 53:899-904. doi:10. 1021/jf048651s

60. Mersmann M, Meier D, Mersmann J, Helmsing S, Nilsson $P$, Gräslund S, et al. Towards proteome scale antibody selections using phage display. $N$ Biotechnol (2010) 27:118-28. doi:10.1016/j. nbt.2009.10.007

61. Mi J, Yan J, Guo Z, Zhao M, Chang W. Isolation and characterization of an anti-recombinant erythropoietin single-chain antibody fragment using a phage display antibody library. Anal Bioanal Chem (2005) 383:218-23. doi:10.1007/ s00216-005-3401-3

62. Bothmann H, Plückthun A. Selection for a periplasmic factor improving phage display and functional periplasmic expression. Nat Biotechnol (1998) 16:376-80. doi: 10.1038/nbt0498-376

63. Bothmann H, Pluckthun A. The periplasmic Escherichia coli peptidyl prolyl cis,trans-isomerase FkpA. I. Increased functional expression of antibody fragments with and without cis-prolines. $J$ Biol Chem (2000) 275:17100-5. doi:10.1074/jbc.M910233199 
64. Friedrich L, Stangl S, Hahne H, Küster B, Köhler P, Multhoff $\mathrm{G}$, et al. Bacterial production and functional characterization of the Fab fragment of the murine IgG1/lambda monoclonal antibody cmHsp70.1, a reagent for tumour diagnostics. Protein Eng Des Sel (2010) 23:161-8. doi:10. 1093/protein/gzp095

65. Ramm K, Plückthun A. The periplasmic Escherichia coli peptidyl prolyl cis,trans-isomerase FkpA. II. Isomerase-independent chaperone activity in vitro. $J$ Biol Chem (2000) 275:17106-13. doi: 10.1074/jbc.M910234199

66. Wiebe JC, Schüller C, Reiche JA, Kramer K, Skerra A, Hock B. An expression system for the $E$. coli fermentation of recombinant antibody Fab fragments from mice and rabbits. J AOAC Int (2010) 93:80-8.

67. Miethe S, Meyer T, Wöhl-Bruhn S, Frenzel A, Schirrmann T, Dübel S, et al. Production of single chain fragment variable $(\mathrm{scFv})$ antibodies in Escherichia coli using the LEX $^{\mathrm{TM}}$ bioreactor. J Biotechnol (2012) 163:105-11. doi:10.1016/j. jbiotec.2012.07.011

68. Sletta H, Nedal A, Aune TEV, Hellebust $\mathrm{H}$, Hakvåg S, Aune R, et al. Broad-host-range plasmid pJB658 can be used for industrial-level production of a secreted hosttoxic single-chain antibody fragment in Escherichia coli. Appl Environ Microbiol (2004) 70:70339. doi:10.1128/AEM.70.12.70337039.2004

69. Kipriyanov SM, Moldenhauer G, Little M. High level production of soluble single chain antibodies in small-scale Escherichia coli cultures. J Immunol Methods (1997) 200:69-77. doi:10.1016/ S0022-1759(96)00188-3

70. Thie H, Binius S, Schirrmann T, Hust $M$, Dübel $S$. Multimerization domains for antibody phage display and antibody production. $N$ Biotechnol (2009) 26:314-21. doi:10.1016/j.nbt.2009.07.005

71. Zhao J-B, Wei D-Z, Tong WY. Identification of Escherichia coli host cell for high plasmid stability and improved production of antihuman ovarian carcinoma $\mathrm{x}$ antihuman CD3 single-chain bispecific antibody. Appl Microbiol Biotechnol (2007) 76:795-800. doi: 10.1007/s00253-007-1050-5

72. Mazor Y, Van Blarcom T, Mabry $\mathrm{R}$, Iverson BL, Georgiou G. Isolation of engineered, full-length antibodies from libraries expressed in Escherichia coli. Nat Biotechnol (2007) 25:563-5. doi:10.1038/ nbt1296

73. Simmons LC, Reilly D, Klimowski L, Raju TS, Meng G, Sims P, et al. Expression of full-length immunoglobulins in Escherichia coli: rapid and efficient production of aglycosylated antibodies. J Immunol Methods (2002) 263:133-47. doi:10.1016/S00221759(02)00036-4

74. Rippmann JF, Klein M, Hoischen C, Brocks B, Rettig WJ, Gumpert $\mathrm{J}$, et al. Procaryotic expression of single-chain variable-fragment (scFv) antibodies: secretion in Lform cells of Proteus mirabilis leads to active product and overcomes the limitations of periplasmic expression in Escherichia coli. Appl Environ Microbiol (1998) 64:4862-9.

75. Dammeyer T, Steinwand M, Krüger S-C, Dübel S, Hust M, Timmis KN. Efficient production of soluble recombinant single chain Fv fragments by a Pseudomonas putida strain KT2440 cell factory. Microb Cell Fact (2011) 10:11. doi:10.1186/1475-2859-10-11

76. Inoue $\mathrm{Y}$, Ohta $\mathrm{T}$, Tada $\mathrm{H}$, Iwasa S, Udaka S, Yamagata H. Efficient production of a functional mouse/human chimeric Fab' against human urokinasetype plasminogen activator by Bacillus brevis. Appl Microbiol Biotechnol (1997) 48:487-92. doi:10.1007/s002530051084

77. Shiroza T, Shinozaki-Kuwahara N, Hayakawa M, Shibata Y, Hashizume T, Fukushima K, et al. Production of a single-chain variable fraction capable of inhibiting the Streptococcus mutans glucosyltransferase in Bacillus brevis: construction of a chimeric shuttle plasmid secreting its gene product. Biochim Biophys Acta (2003) 1626:57-64. doi:10.1016/ S0167-4781(03)00038-1

78. Wu SC, Ye R, Wu XC, Ng SC, Wong SL. Enhanced secretory production of a single-chain antibody fragment from Bacillus subtilis by co-production of molecular chaperones. J Bacteriol (1998) 180:2830-5.

79. Wu S-C, Yeung JC, Duan Y, Ye R, Szarka SJ, Habibi HR, et al. Functional production and characterization of a fibrin-specific singlechain antibody fragment from Bacillus subtilis: effects of molecular chaperones and a wall-bound protease on antibody fragment production. Appl Environ Microbiol (2002) 68:3261-9. doi:10. 1128/AEM.68.7.3261-3269.2002

80. David F, Steinwand M, Hust M, Bohle K, Ross A, Dübel S, et al. Antibody production in Bacillus megaterium: strategies and physiological implications of scaling from microtiter plates to industrial bioreactors. Biotechnol J (2011) 6:1516-31. doi:10.1002/ biot. 201000417

81. David F, Westphal R, Bunk B, Jahn D, Franco-Lara E. Optimization of antibody fragment production in Bacillus megaterium: the role of metal ions on protein secretion. J Biotechnol (2010) 150:115-24. doi: 10.1016/j.jbiotec.2010.07.023

82. Jordan E, Al-Halabi L, Schirrmann T, Hust M. Antibody production by the Gram-positive bacterium Bacillus megaterium. Methods Mol Biol (2009) 525:509-16. doi:10. 1007/978-1-59745-554-1_27

83. Jordan E, Al-Halabi L, Schirrmann T, Hust M, Dübel S. Production of single chain Fab (scFab) fragments in Bacillus megaterium. Microb Cell Fact (2007) 6:38. doi: 10.1186/1475-2859-6-2

84. Jordan E, Hust M, Roth A, Biedendieck R, Schirrmann T, Jahn $\mathrm{D}$, et al. Production of recombinant antibody fragments in Bacillus megaterium. Microb Cell Fact (2007) 6:2. doi:10.1186/14752859-6-2

85. Lüders S, David F, Steinwand M, Jordan E, Hust M, Dübel S, et al. Influence of the hydromechanical stress and temperature on growth and antibody fragment production with Bacillus megaterium. Appl Microbiol Biotechnol (2011) 91:81-90. doi:10.1007/ s00253-011-3193-7

86. Vary PS. Prime time for Bacillus megaterium. Microbiology (1994) 140(Pt 5):1001-13. doi:10.1099/ 13500872-140-5-1001

87. Chancey CJ, Khanna KV, Seegers JFML, Zhang GW, Hildreth J, Langan A, et al. Lactobacilli-expressed single-chain variable fragment (scFv) specific for intercellular adhesion molecule 1 (ICAM-1) blocks cell-associated HIV-1 transmission across a cervical epithelial monolayer. J Immunol (2006) 176:5627-36.

88. Krüger $\mathrm{C}, \mathrm{Hu} \mathrm{Y}$, Pan Q, Marcotte H, Hultberg A, Delwar D, et al. In situ delivery of passive immunity by lactobacilli producing single-chain antibodies. Nat Biotechnol (2002) 20:702-6. doi: 10.1038/nbt0702-702
89. Marcotte H, Kõll-Klais P, Hultberg A, Zhao Y, Gmür R, Mändar R, et al. Expression of singlechain antibody against RgpA protease of Porphyromonas gingivalis in Lactobacillus. J Appl Microbiol (2006) 100:256-63. doi:10.1111/j. 1365-2672.2005.02786.x

90. De Pourcq K, Vervecken W, Dewerte I, Valevska A, Van Hecke A, Callewaert N. Engineering the yeast Yarrowia lipolytica for the production of therapeutic proteins homogeneously glycosylated with $\mathrm{Man}_{8} \mathrm{GlcNAc}_{2}$ and Man $\mathrm{GlcNAc}_{2}$. Microb Cell Fact (2012) 11:53. doi:10.1186/1475-2859-11-53

91. Schreuder MP, Mooren AT, Toschka HY, Verrips CT, Klis FM. Immobilizing proteins on the surface of yeast cells. Trends Biotechnol (1996) 14:115-20. doi: 10.1016/0167-7799(96)10017-2

92. Jeong KJ, Jang SH, Velmurugan N. Recombinant antibodies: engineering and production in yeast and bacterial hosts. Biotechnol J (2011) 6:16-27. doi:10.1002/biot. 201000381

93. Davis GT, Bedzyk WD, Voss EW, Jacobs TW. Single chain antibody (SCA) encoding genes: one-step construction and expression in eukaryotic cells. Biotechnology (N Y) (1991) 9:165-9. doi:10.1038/ nbt0291-165

94. Fleer R. Engineering yeast for high level expression. Curr Opin Biotechnol (1992) 3:486-96. doi: 10.1016/0958-1669(92)90076-U

95. Buckholz RG, Gleeson MA. Yeast systems for the commercial production of heterologous proteins. Biotechnology (N Y) (1991) 9:1067-72. doi:10.1038/nbt11911067

96. Gasser B, Maurer M, Gach J, Kunert R, Mattanovich D. Engineering of Pichia pastoris for improved production of antibody fragments. Biotechnol Bioeng (2006) 94:353-61. doi:10.1002/bit. 20851

97. Emberson LM, Trivett AJ, Blower PJ, Nicholls PJ. Expression of an anti-CD33 single-chain antibody by Pichia pastoris. J Immunol Methods (2005) 305:135-51. doi:10. 1016/j.jim.2005.04.005

98. Ridder R, Schmitz R, Legay F, Gram H. Generation of rabbit monoclonal antibody fragments from a combinatorial phage display library and their production in the yeast Pichia pastoris. Biotechnology (N Y) (1995) 13:255-60. doi:10.1038/nbt0395-255 
99. Gurkan C, Symeonides SN, Ellar DJ. High-level production in Pichia pastoris of an anti-p185HER-2 single-chain antibody fragment using an alternative secretion expression vector. Biotechnol Appl Biochem (2004) 39:115-22. doi:10.1042/BA20030096

100. Eldin P, Pauza ME, Hieda Y, Lin G, Murtaugh MP, Pentel PR, et al. High-level secretion of two antibody single chain $\mathrm{Fv}$ fragments by Pichia pastoris. J Immunol Methods (1997) 201:67-75. doi:10. 1016/S0022-1759(96)00213-X

101. Damasceno LM, Anderson KA, Ritter G, Cregg JM, Old LJ, Batt CA. Cooverexpression of chaperones for enhanced secretion of a single-chain antibody fragment in Pichia pastoris. Appl Microbiol Biotechnol (2007) 74:381-9. doi: 10.1007/s00253-006-0652-7

102. Frenken LG, van der Linden RH, Hermans PW, Bos JW, Ruuls $\mathrm{RC}$, de Geus B, et al. Isolation of antigen specific llama VHH antibody fragments and their high level secretion by Saccharomyces cerevisiae. J Biotechnol (2000) 78:11-21. doi:10.1016/ S0168-1656(99)00228-X

103. Liu J, Wei D, Qian F, Zhou Y, Wang J, Ma Y, et al. pPIC9Fc: a vector system for the production of single-chain $\mathrm{Fv}-\mathrm{Fc}$ fusions in Pichia pastoris as detection reagents in vitro. $J$ Biochem (2003) 134:911-7. doi:10.1093/jb/ $\operatorname{mvg} 222$

104. Horwitz AH, Chang CP, Better M, Hellstrom KE, Robinson RR. Secretion of functional antibody and Fab fragment from yeast cells. Proc Natl Acad Sci U S A (1988) 85:8678-82. doi:10.1073/pnas.85. 22.8678

105. Potgieter TI, Kersey SD, Mallem MR, Nylen AC, d'Anjou M. Antibody expression kinetics in glycoengineered Pichia pastoris. Biotechnol Bioeng (2010) 106:918-27. doi: 10.1002/bit.22756

106. Van der Linden RH, de Geus B, Frenken GJ, Peters H, Verrips CT. Improved production and function of llama heavy chain antibody fragments by molecular evolution. JBiotechnol (2000) 80:261-70. doi: 10.1016/S0168-1656(00)00274-1

107. Shusta EV, Raines RT, Plückthun A, Wittrup KD. Increasing the secretory capacity of Saccharomyces cerevisiae for production of singlechain antibody fragments. Nat Biotechnol (1998) 16:773-7. doi: 10.1038/nbt0898-773
108. Grinna LS, Tschopp JF. Size distribution and general structural features of $\mathrm{N}$-linked oligosaccharides from the methylotrophic yeast, Pichia pastoris. Yeast (1989) 5:10715. doi:10.1002/yea.320050206

109. Choi B-K, Bobrowicz P, Davidson RC, Hamilton SR, Kung DH, Li $\mathrm{H}$, et al. Use of combinatorial genetic libraries to humanize Nlinked glycosylation in the yeast Pichia pastoris. Proc Natl Acad Sci U S A (2003) 100:5022-7. doi:10. 1073/pnas.0931263100

110. Hamilton SR, Davidson RC, Sethuraman N, Nett JH, Jiang Y, Rios $S$, et al. Humanization of yeast to produce complex terminally sialylated glycoproteins. Science (2006) 313:1441-3. doi:10.1126/science. 1130256

111. Hamilton SR, Bobrowicz P, Bobrowicz B, Davidson RC, Li H, Mitchell T, et al. Production of complex human glycoproteins in yeast. Science (2003) 301:1244-6. doi:10.1126/science. 1088166

112. Li H, Sethuraman N, Stadheim TA, Zha D, Prinz B, Ballew N, et al. Optimization of humanized IgGs in glycoengineered Pichia pastoris. Nat Biotechnol (2006) 24:210-5. doi:10.1038/nbt1178

113. Potgieter TI, Cukan M, Drummond JE, Houston-Cummings NR, Jiang Y, Li F, et al. Production of monoclonal antibodies by glycoengineered Pichia pastoris. J Biotechnol (2009) 139:318-25. doi: 10.1016/j.jbiotec.2008.12.015

114. Zhang N, Liu L, Dumitru CD, Cummings NRH, Cukan M, Jiang $\mathrm{Y}$, et al. Glycoengineered Pichia produced anti-HER2 is comparable to trastuzumab in preclinical study. MAbs (2011) 3:289-98. doi: 10.4161/mabs.3.3.15532

115. Ye J, Ly J, Watts K, Hsu A, Walker A, McLaughlin K, et al. Optimization of a glycoengineered Pichia pastoris cultivation process for commercial antibody production. Biotechnol Prog (2011) 27:174450. doi:10.1002/btpr.695

116. Jiang Y, Li F, Button M, Cukan M, Moore R, Sharkey N, et al. A highthroughput purification of monoclonal antibodies from glycoengineered Pichia pastoris. Protein Expr Purif (2010) 74:9-15. doi:10.1016/ j.pep. 2010.04 .016

117. Joosten V, Lokman C, Van Den Hondel CA, Punt PJ. The production of antibody fragments and antibody fusion proteins by yeasts and filamentous fungi. Microb Cell Fact (2003) 2:1. doi:10.1186/14752859-2-1
118. Ward M, Lin C, Victoria DC, Fox BP, Fox JA, Wong DL, et al. Characterization of humanized antibodies secreted by Aspergillus niger. Appl Environ Microbiol (2004) 70:2567-76. doi:10.1128/AEM.70. 5.2567-2576.2004

119. Joosten V, Gouka RJ, van den Hondel CAMJJ, Verrips CT, Lokman BC. Expression and production of llama variable heavy-chain antibody fragments $(\mathrm{V}(\mathrm{HH}) \mathrm{s})$ by Aspergillus awamori. Appl Microbiol Biotechnol (2005) 66:384-92. doi:10.1007/s00253-004-1689-0

120. Frenken LG, Hessing JG, Van den Hondel CA, Verrips CT. Recent advances in the largescale production of antibody fragments using lower eukaryotic microorganisms. Res Immunol (1998) 149:589-99. doi:10.1016/ S0923-2494(98)80011-4

121. Nyyssönen E, Penttilä M, Harkki A, Saloheimo A, Knowles JK, Keränen S. Efficient production of antibody fragments by the filamentous fungus Trichoderma reesei. Biotechnology (N Y) (1993) 11:591-5. doi:10. 1038/nbt0593-591

122. Joosten V, Roelofs MS, van den Dries N, Goosen T, Verrips CT, van den Hondel CAMJJ, et al. Production of bifunctional proteins by Aspergillus awamori: llama variable heavy chain antibody fragment $(\mathrm{V}(\mathrm{HH}))$ R9 coupled to Arthromyces ramosus peroxidase (ARP). J Biotechnol (2005) 120:347-59. doi:10.1016/j.jbiotec. 2005.06.034

123. Okazaki F, Aoki J, Tabuchi S, Tanaka T, Ogino C, Kondo A Efficient heterologous expression and secretion in Aspergillus oryzae of a llama variable heavy-chain antibody fragment $\mathrm{V}(\mathrm{HH})$ against EGFR. Appl Microbiol Biotechnol (2012) 96:81-8. doi:10.1007/ s00253-012-4158-1

124. Verdoes JC, Punt PJ, Burlingame R, Bartels J, Dijk R, van Slump E, et al. ORIGINAL RESEARCH: a dedicated vector for efficient library construction and high throughput screening in the hyphal fungus Chrysosporium lucknowense. Ind Biotechnol (2007) 3:48-57. doi: 10.1089/ind.2007.3.048

125. Basile G, Peticca M. Recombinant protein expression in Leishmania tarentolae. Mol Biotechnol (2009) 43:273-8. doi:10.1007/ s12033-009-9213-5

126. Niimi T. Recombinant protein production in the eukaryotic protozoan parasite Leishmania tarentolae: a review. Methods Mol Biol
(2012) 824:307-15. doi:10.1007/ 978-1-61779-433-9_15

127. Klatt S, Rohe M, Alagesan K, Kolarich D, Konthur Z, Hartl D. Production of glycosylated soluble amyloid precursor protein alpha (sAPPalpha) in Leishmania tarentolae. J Proteome Res (2013) 12:396-403. doi:10.1021/ pr300693f

128. Klatt S, Konthur Z. Secretory signal peptide modification for optimized antibodyfragment expression-secretion in Leishmania tarentolae. Microb Cell Fact (2012) 11:97. doi:10.1186/1475-2859-11-97

129. Condreay JP, Witherspoon SM, Clay WC, Kost TA. Transient and stable gene expression in mammalian cells transduced with a recombinant baculovirus vector. Proc Natl Acad Sci U S A (1999) 96:127-32. doi:10.1073/pnas.96.1. 127

130. Hofmann C, Sandig V, Jennings G, Rudolph M, Schlag P, Strauss M. Efficient gene transfer into human hepatocytes by baculovirus vectors. Proc Natl Acad Sci U S A (1995) 92:10099-103. doi:10. 1073/pnas.92.22.10099

131. Davis TR, Wickham TJ, McKenna KA, Granados RR, Shuler ML, Wood HA. Comparative recombinant protein production of eight insect cell lines. In vitro Cell Dev Biol Anim (1993) 29A:388-90. doi: 10.1007/BF02633986

132. Kretzschmar T, Aoustin L, Zingel $\mathrm{O}$, Marangi M, Vonach B, Towbin $\mathrm{H}$, et al. High-level expression in insect cells and purification of secreted monomeric singlechain $\mathrm{Fv}$ antibodies. $J$ Immunol Methods (1996) 195:93-101. doi: 10.1016/0022-1759(96)00093-2

133. Liang M, Dübel S, Li D, Queitsch I, Li W, Bautz EK. Baculovirus expression cassette vectors for rapid production of complete human IgG from phage display selected antibody fragments. J Immunol Methods (2001) 247:119-30. doi:10.1016/S00221759(00)00322-7

134. Hsu TA, Takahashi N, Tsukamoto Y, Kato K, Shimada I, Masuda K, et al. Differential N-glycan patterns of secreted and intracellular IgG produced in Trichoplusia ni cells. J Biol Chem (1997) 272:9062-70. doi:10.1074/jbc.272.14.9062

135. Jin BR, Ryu CJ, Kang SK, Han $\mathrm{MH}$, Hong HJ. Characterization of a murine-human chimeric antibody with specificity for the preS2 surface antigen of hepatitis B 
virus expressed in baculovirusinfected insect cells. Virus Res (1995) 38:269-77. doi:10.1016/ 0168-1702(95)00051-Q

136. Zu Putlitz J, Kubasek WL, Duchêne M, Marget M, von Specht BU, Domdey H. Antibody production in baculovirus-infected insect cells. Biotechnology (N Y) (1990) 8:651-4. doi:10.1038/nbt0790-651

137. Edelman L, Margaritte C, Chaabihi $\mathrm{H}$, Monchâtre E, Blanchard D, Cardona A, et al. Obtaining a functional recombinant antirhesus (D) antibody using the baculovirus-insect cell expression system. Immunology (1997) 91:139. doi:10.1046/j.1365-2567.1997. 00219.x

138. Ailor E, Betenbaugh MJ. Modifying secretion and posttranslational processing in insect cells. Curr Opin Biotechnol (1999) 10:142-5. doi:10.1016/S09581669(99)80024-X

139. Aumiller JJ, Mabashi-Asazuma H, Hillar A, Shi X, Jarvis DL. A new glycoengineered insect cell line with an inducibly mammalianized protein N-glycosylation pathway. Glycobiology (2012) 22:41728. doi:10.1093/glycob/cwr160

140. Jarvis DL. Developing baculovirus-insect cell expression systems for humanized recombinant glycoprotein production. Virology (2003) 310:1-7. doi:10. 1016/S0042-6822(03)00120-X

141. Tomiya N, Betenbaugh MJ, Lee YC. Humanization of lepidopteran insect-cell-produced glycoproteins. Acc Chem Res (2003) 36:613-20. doi:10.1021/ar020202v

142. Hasemann CA, Capra JD. Highlevel production of a functional immunoglobulin heterodimer in a baculovirus expression system. Proc Natl Acad Sci U S A (1990) 87:3942-6. doi:10.1073/ pnas.87.10.3942

143. Hsu TA, Betenbaugh MJ. Coexpression of molecular chaperone $\mathrm{BiP}$ improves immunoglobulin solubility and IgG secretion from Trichoplusia ni insect cells. Biotechnol Prog (1997) 13:96-104. doi:10.1021/bp960088d

144. Reavy B, Ziegler A, Diplexcito J, MacIntosh SM, Torrance L, Mayo M. Expression of functional recombinant antibody molecules in insect cell expression systems. Protein Expr Purif (2000) 18:2218. doi:10.1006/prep.1999.1191

145. Seamans TC, Gould SL, DiStefano DJ, Silberklang M, Robinson DK. Use of lipid emulsions as nutritional supplements in mammalian cell culture. Ann N Y Acad Sci (1994) 745:240-3. doi:10.1111/j. 1749-6632.1994.tb44377.x

146. Wurm FM. Production of recombinant protein therapeutics in cultivated mammalian cells. Nat Biotechnol (2004) 22:1393-8. doi: $10.1038 / \mathrm{nbt} 1026$

147. Jones D, Kroos N, Anema R, van Montfort B, Vooys A, van der Kraats S, et al. High-level expression of recombinant IgG in the human cell line per.c6. Biotechnol Prog (2003) 19:163-8. doi:10. 1021/bp025574h

148. Butler M. Animal cell cultures: recent achievements and perspectives in the production of biopharmaceuticals. Appl Microbiol Biotechnol (2005) 68:283-91. doi: 10.1007/s00253-005-1980-8

149. Fussenegger M, Bailey JE. Molecular regulation of cell-cycle progression and apoptosis in mammalian cells: implications for biotechnology. Biotechnol Prog (1998) 14:807-33. doi:10.1021/ bp9800891

150. Lifely MR, Hale C, Boyce S, Keen MJ, Phillips J. Glycosylation and biological activity of CAMPATH$1 \mathrm{H}$ expressed in different cell lines and grown under different culture conditions. Glycobiology (1995) 5:813-22. doi:10.1093/glycob/5.8. 813

151. Niklas J, Schräder E, Sandig V, Noll T, Heinzle E. Quantitative characterization of metabolism and metabolic shifts during growth of the new human cell line AGE1.HN using time resolved metabolic flux analysis. Bioprocess Biosyst Eng (2011) 34:533-45. doi: 10.1007/s00449-010-0502-y

152. Shields RL, Lai J, Keck R, O’Connell LY, Hong K, Meng YG, et al. Lack of fucose on human IgG1 N-linked oligosaccharide improves binding to human Fcgamma RIII and antibody-dependent cellular toxicity. J Biol Chem (2002) 277:2673340. doi:10.1074/jbc.M202069200

153. Le Hir H, Nott A, Moore MJ. How introns influence and enhance eukaryotic gene expression. Trends Biochem Sci (2003) 28:215-20. doi: 10.1016/S0968-0004(03)00052-5

154. Nott A, Le Hir H, Moore MJ. Splicing enhances translation in mammalian cells: an additional function of the exon junction complex. Genes Dev (2004) 18:210-22. doi:10.1101/gad.1163204

155. Li J, Menzel C, Meier D, Zhang C, Dübel S, Jostock T. A comparative study of different vector designs for the mammalian expression of recombinant IgG antibodies. I Immunol Methods (2007) 318:113-24. doi:10.1016/j. jim.2006.10.010

156. Li J, Zhang C, Jostock T, Dübel S. Analysis of IgG heavy chain to light chain ratio with mutant Encephalomyocarditis virus internal ribosome entry site. Protein Eng Des Sel (2007) 20:491-6. doi:10. 1093/protein/gzm038

157. Omasa T. Gene amplification and its application in cell and tissue engineering. $J$ Biosci Bioeng (2002) 94:600-5. doi:10.1016/ S1389-1723(02)80201-8

158. Peakman TC, Worden J, Harris $\mathrm{RH}$, Cooper H, Tite J, Page MJ, et al. Comparison of expression of a humanized monoclonal antibody in mouse NSO myeloma cells and Chinese hamster ovary cells. Hum Antibodies Hybridomas (1994) 5:65-74.

159. Spier RE, Griffiths JB, Berthold W. Animal Cell Technology: Products of Today, Prospects for Tomorrow. Oxford: Butterworth-Heinemann Limited (1994).

160. Zhou W, Chen CC, Buckland B, Aunins J. Fed-batch culture of recombinant NSO myeloma cells with high monoclonal antibody production. Biotechnol Bioeng (1997) 55:783-92. doi:10.1002/ (SICI) 1097-0290(19970905)55:5

161. Jostock T. Expression of antibody in mammalian cells. In: AlRubeai M editor. Antibody Expression and Production, Cell Engineering. Netherlands: Springer (2011). p. 1-24.

162. Girod P-A, Mermod N. Use of scaffold/matrix-attachment regions for protein production. In: Makrides SC editor. New Comprehensive Biochemistry. Amsterdam, NL: Elsevier (2003). p. 359-79.

163. Antoniou M, Harland L, Mustoe T, Williams S, Holdstock J, Yague E, et al. Transgenes encompassing dualpromoter $\mathrm{CpG}$ islands from the human TBP and HNRPA2B1 loci are resistant to heterochromatinmediated silencing. Genomics (2003) 82:269-79. doi:10.1016/ S0888-7543(03)00107-1

164. Kwaks THJ, Barnett P, Hemrika W, Siersma T, Sewalt RGAB, Satijn DPE, et al. Identification of antirepressor elements that confer high and stable protein production in mammalian cells. Nat Biotechnol (2003) 21:553-8. doi:10.1038/ nbt814

165. Fernández LA, Winkler M, Grosschedl R. Matrix attachment region-dependent function of the immunoglobulin mu enhancer involves histone acetylation at a distance without changes in enhancer occupancy. Mol Cell Biol (2001) 21:196-208. doi:10.1128/ MCB.21.1.196-208.2001

166. Zahn-Zabal M, Kobr M, Girod PA, Imhof M, Chatellard P, de Jesus $M$, et al. Development of stable cell lines for production or regulated expression using matrix attachment regions. J Biotechnol (2001) 87:29-42. doi:10.1016/ S0168-1656(00)00423-5

167. Gorman CM, Howard BH, Reeves R. Expression of recombinant plasmids in mammalian cells is enhanced by sodium butyrate. Nucleic Acids Res (1983) 11:763148. doi:10.1093/nar/11.21.7631

168. Classon BJ, Brown MH, Garnett D, Somoza C, Barclay AN, Willis $\mathrm{AC}$, et al. The hinge region of the CD8 alpha chain: structure, antigenicity, and utility in expression of immunoglobulin superfamily domains. Int Immunol (1992) 4:215-25. doi:10.1093/intimm/4. 2.215

169. Kober L, Zehe C, Bode J. Development of a novel ER stress based selection system for the isolation of highly productive clones. Biotechnol Bioeng (2012) 109:2599-611. doi:10.1002/bit.24527

170. Nehlsen K, Schucht R, da GamaNorton L, Krömer W, Baer A, Cayli A, et al. Recombinant protein expression by targeting preselected chromosomal loci. BMC Biotechnol (2009) 9:100. doi:10. 1186/1472-6750-9-100

171. Fang J, Yi S, Simmons A, Tu GH, Nguyen M, Harding TC, et al. An antibody delivery system for regulated expression of therapeutic levels of monoclonal antibodies in vivo. Mol Ther (2007) 15:11539.

172. Jostock T, Dragic Z, Fang J, Jooss K, Wilms B, Knopf H-P. Combination of the $2 \mathrm{~A} /$ furin technology with an animal component free cell line development platform process. Appl Microbiol Biotechnol (2010) 87:1517-24. doi:10.1007/ s00253-010-2625-0

173. Wilke S, Groebe L, Maffenbeier V, Jäger V, Gossen M, Josewski J, et al. Streamlining homogeneous glycoprotein production for biophysical and structural applications by targeted cell line development. PLoS ONE (2011) 6:e27829. doi: 10.1371/journal.pone.0027829

174. Geisse S, Fux C. Recombinant protein production by transient gene transfer into Mammalian 
cells. Methods Enzymol (2009) 463:223-38. doi:10.1016/S00766879(09)63015-9

175. Baldi L, Hacker DL, Adam M, Wurm FM. Recombinant protein production by large-scale transient gene expression in mammalian cells: state of the art and future perspectives. Biotechnol Lett (2007) 29:677-84. doi:10. 1007/s10529-006-9297-y

176. Jostock T, Vanhove M, Brepoels E, Van Gool R, Daukandt M, Wehnert A, et al. Rapid generation of functional human IgG antibodies derived from Fab-on-phage display libraries. J Immunol Methods (2004) 289:65-80. doi:10.1016/j. jim.2004.03.014

177. Backliwal G, Hildinger M, Chenuet S, Wulhfard S, De Jesus $M$, Wurm FM. Rational vector design and multi-pathway modulation of HEK 293E cells yield recombinant antibody titers exceeding $1 \mathrm{~g} / \mathrm{l}$ by transient transfection under serum-free conditions. Nucleic Acids Res (2008) 36:e96. doi:10.1093/nar/gkn423

178. Geisse S, Henke M. Large-scale transient transfection of mammalian cells: a newly emerging attractive option for recombinant protein production. J Struct Funct Genomics (2005) 6:165-70. doi:10. 1007/s10969-005-2826-4

179. Tuvesson O, Uhe C, Rozkov A, Lüllau E. Development of a generic transient transfection process at $100 \mathrm{~L}$ scale. Cytotechnology (2008) 56:123-36. doi:10. 1007/s10616-008-9135-2

180. Meissner P, Pick H, Kulangara A, Chatellard P, Friedrich K, Wurm FM. Transient gene expression: recombinant protein production with suspension-adapted HEK293-EBNA cells. Biotechnol Bioeng (2001) 75:197-203. doi:10. 1002/bit.1179

181. Boussif O, Zanta MA, Behr JP. Optimized galenics improve in vitro gene transfer with cationic molecules up to 1000 -fold. Gene Ther (1996) 3:1074-80.

182. Thomas M, Klibanov AM. Enhancing polyethylenimine's delivery of plasmid DNA into mammalian cells. Proc Natl Acad Sci U S A (2002) 99:14640-5. doi:10.1073/pnas.192581499

183. Loignon M, Perret S, Kelly J, Boulais D, Cass B, Bisson L, et al. Stable high volumetric production of glycosylated human recombinant IFNalpha2b in HEK293 cells. BMC Biotechnol (2008) 8:65. doi: 10.1186/1472-6750-8-65
184. Zhang J, MacKenzie R, Durocher Y. Production of chimeric heavychain antibodies. Methods Mol Biol (2009) 525:323-36. doi:10.1007/ 978-1-59745-554-1_17

185. Daniell H, Streatfield SJ, Wycoff K. Medical molecular farming: production of antibodies, biopharmaceuticals and edible vaccines in plants. Trends Plant Sci (2001) 6:219-26. doi:10.1016/ S1360-1385(01)01922-7

186. Hellens RP, Edwards EA, Leyland NR, Bean S, Mullineaux PM. pGreen: a versatile and flexible binary $\mathrm{Ti}$ vector for Agrobacterium-mediated plant transformation. Plant Mol Biol (2000) 42:819-32. doi:10.1023/A:1006496308160

187. Hoekema A, Hirsch PR, Hooykaas PJJ, Schilperoort RA. A binary plant vector strategy based on separation of vir- and T-region of the Agrobacterium tumefaciens Tiplasmid. Nature (1983) 303:17980. doi: $10.1038 / 303179 \mathrm{a} 0$

188. Amian AA, Papenbrock J, Jacobsen H-J, Hassan F. Enhancing transgenic pea (Pisum sativum L.) resistance against fungal diseases through stacking of two antifungal genes (chitinase and glucanase). GM Crops (2011) 2:104-9. doi:10. 4161/gmcr.2.2.16125

189. Horsch RB, Fry JE, Hofmann NL, Eichholz D, Rogers SG, Fraley RT. A simple and general method for transferring genes into plants. Science (1985) 227:1229-31. doi:10. 1126/science.227.4691.1229

190. McCormickAA, Reinl SJ, Cameron TI, Vojdani F, Fronefield M, Levy $\mathrm{R}$, et al. Individualized human scFv vaccines produced in plants: humoral anti-idiotype responses in vaccinated mice confirm relevance to the tumor Ig. J Immunol Methods (2003) 278:95-104. doi: 10.1016/S0022-1759(03)00208-4

191. McCormick AA, Reddy S, Reinl SJ, Cameron TI, Czerwinkski DK, Vojdani F, et al. Plant-produced idiotype vaccines for the treatment of non-Hodgkin's lymphoma: safety and immunogenicity in a phase I clinical study. Proc Natl Acad Sci US A (2008) 105:10131-6. doi:10. 1073/pnas.0803636105

192. Gomord V, Chamberlain P, Jefferis R, Faye L. Biopharmaceutical production in plants: problems, solutions and opportunities. Trends Biotechnol (2005) 23:559-65. doi: 10.1016/j.tibtech.2005.09.003

193. Jin C, Altmann F, Strasser R, Mach L, Schähs $M$, Kunert $R$, et al. A plant-derived human monoclonal antibody induces an anti-carbohydrate immune response in rabbits. Glycobiology (2008) 18:235-41. doi:10.1093/glycob/cwm137

194. Walsh G, Jefferis R. Posttranslational modifications in the context of therapeutic proteins. Nat Biotechnol (2006) 24:1241-52. doi:10.1038/nbt1252

195. Gomord V, Denmat LA, FitchetteLainé AC, Satiat-Jeunemaitre B, Hawes C, Faye L. The C-terminal HDEL sequence is sufficient for retention of secretory proteins in the endoplasmic reticulum (ER) but promotes vacuolar targeting of proteins that escape the ER. Plant $J$ (1997) 11:313-25. doi:10.1046/j. 1365-313X.1997.11020313.x

196. Schouten A, Roosien J, de Boer JM, Wilmink A, Rosso MN, Bosch D, et al. Improving $\mathrm{scFv}$ antibody expression levels in the plant cytosol. FEBS Lett (1997) 415:235-41. doi:10.1016/ S0014-5793(97)01129-0

197. Schouten A, Roosien J, van Engelen FA, de Jong GA, Borst-Vrenssen AW, Zilverentant JF, et al. The Cterminal KDEL sequence increases the expression level of a singlechain antibody designed to be targeted to both the cytosol and the secretory pathway in transgenic tobacco. Plant $\mathrm{Mol}$ Biol (1996) 30:781-93. doi:10.1007/ BF00019011

198. Schähs M, Strasser R, Stadlmann J, Kunert R, Rademacher T, Steinkellner H. Production of a monoclonal antibody in plants with a humanized N-glycosylation pattern. Plant Biotechnol J (2007) 5:657-63. doi:10.1111/j.14677652.2007.00273.x

199. Strasser R, Stadlmann J, Schähs M, Stiegler G, Quendler H, Mach L, et al. Generation of glyco-engineered Nicotiana benthamiana for the production of monoclonal antibodies with a homogeneous human-like $\mathrm{N}$ glycan structure. Plant Biotechnol $J$ (2008) 6:392-402. doi:10.1111/j. 1467-7652.2008.00330.x

200. Yin B-J, Gao T, Zheng N-Y, Li Y, Tang S-Y, Liang L-M, et al. Generation of glyco-engineered BY2 cell lines with decreased expression of plant-specific glycoepitopes. Protein Cell (2011) 2:41-7. doi:10. 1007/s13238-011-1007-4

201. Vézina L-P, Faye L, Lerouge P, D'Aoust M-A, Marquet-Blouin E, Burel C, et al. Transient coexpression for fast and high-yield production of antibodies with human-like N-glycans in plants. Plant Biotechnol J (2009) 7:44255. doi:10.1111/j.1467-7652.2009. 00414.x

202. Jez J, Castilho A, Grass J, VorauerUhl K, Sterovsky T, Altmann F, et al. Expression of functionally active sialylated human erythropoietin in plants. Biotechnol J (2013) 8:37182. doi:10.1002/biot.201200363

203. Castilho A, Neumann L, Daskalova $\mathrm{S}$, Mason HS, Steinkellner $\mathrm{H}$, Altmann F, et al. Engineering of sialylated mucin-type Oglycosylation in plants. J Biol Chem (2012) 287:36518-26. doi: 10.1074/jbc.M112.402685

204. Yang Z, Drew DP, Jørgensen B, Mandel U, Bach SS, Ulvskov P, et al. Engineering mammalian mucin-type $\mathrm{O}$ glycosylation in plants. $J$ Biol Chem (2012) 287:11911-23. doi:10.1074/jbc.M111.312918

205. Mett V, Chichester JA, Stewart ML, Musiychuk K, Bi H, Reifsnyder CJ, et al. A non-glycosylated, plant-produced human monoclonal antibody against anthrax protective antigen protects mice and non-human primates from B. anthracis spore challenge. Hum Vaccin (2011) 7:183-90. doi:10. 4161/hv.7.0.14586

206. Rodríguez M, Pérez L, Gavilondo JV, Garrido G, Bequet-Romero M, Hernández I, et al. Comparative in vitro and experimental in vivo studies of the antiepidermal growth factor receptor antibody nimotuzumab and its aglycosylated form produced in transgenic tobacco plants. Plant Biotechnol J (2013) 11:53-65. doi: 10.1111/pbi.12006

207. Marillonnet S, Thoeringer C, Kandzia R, Klimyuk V, Gleba Y. Systemic Agrobacterium tumefaciens-mediated transfection of viral replicons for efficient transient expression in plants. Nat Biotechnol (2005) 23:718-23. doi: 10.1038/nbt1094

208. Giritch A, Marillonnet S, Engler C, van Eldik G, Botterman J, Klimyuk $\mathrm{V}$, et al. Rapid high-yield expression of full-size IgG antibodies in plants coinfected with noncompeting viral vectors. Proc Natl Acad Sci U S A (2006) 103:14701-6. doi:10.1073/pnas.0606631103

209. Barros GOF, Woodard SL, Nikolov ZL. Phenolics removal from transgenic Lemna minor extracts expressing $\mathrm{mAb}$ and impact on mAb production cost. Biotechnol Prog (2011) 27:410-8. doi:10.1002/btpr.543 
210. Naik AD, Menegatti S, Reese HR, Gurgel PV, Carbonell RG. Process for purification of monoclonal antibody expressed in transgenic Lemna plant extract using dextran-coated charcoal and hexamer peptide affinity resin. J Chromatogr A (2012) 1260: 61-6. doi:10.1016/j.chroma.2012. 08.043

211. Woodard SL, Wilken LR, Barros GOF, White SG, Nikolov ZL. Evaluation of monoclonal antibody and phenolic extraction from transgenic Lemna for purification process development. Biotechnol Bioeng (2009) 104:562-71. doi:10. 1002/bit.22428

212. Torres E, Vaquero C, Nicholson L, Sack M, Stöger E, Drossard $J$, et al. Rice cell culture as an alternative production system for functional diagnostic and therapeutic antibodies. Transgenic Res (1999) 8:441-9. doi:10.1023/A: 1008969031219

213. Buck SD, Virdi V, Meyer TD, Wilde KD, Piron R, Nolf J, et al. Production of Camel-like antibodies in plants. In: Saerens D, Muyldermans S editors. Single Domain Antibodies, Methods in Molecular Biology. Clifton, NJ: Humana Press (2012). p. 305-24.

214. De Wilde K, De Buck S, Vanneste K, Depicker A. Recombinant antibody production in Arabidopsis seeds triggers an unfolded protein response. Plant Physiol (2012) 161:1021-33. doi:10.1104/pp.112. 209718

215. Bardor M, Loutelier-Bourhis C, Paccalet T, Cosette P, Fitchette A-C, Vézina L-P, et al. Monoclonal C5-1 antibody produced in transgenic alfalfa plants exhibits a Nglycosylation that is homogenous and suitable for glyco-engineering into human-compatible structures. Plant Biotechnol J (2003) 1:451-62. doi:10.1046/j.14677652.2003.00041.x

216. He J, Lai H, Brock C, Chen Q. A novel system for rapid and costeffective production of detection and diagnostic reagents of West Nile virus in plants. J Biomed Biotechnol (2012) 2012:106783. doi:10.1155/2012/106783

217. Rademacher T, Sack M, Arcalis E, Stadlmann J, Balzer S, Altmann F, et al. Recombinant antibody 2G12 produced in maize endosperm efficiently neutralizes HIV-1 and contains predominantly singleGlcNAc N-glycans. Plant Biotechnol J (2008) 6:189-201. doi:10. 1111/j.1467-7652.2007.00306.x
218. Ramessar K, Rademacher T, Sack M, Stadlmann J, Platis D, Stiegler $G$, et al. Cost-effective production of a vaginal protein microbicide to prevent HIV transmission. Proc Natl Acad Sci U S A (2008) 105:3727-32. doi:10.1073/ pnas.0708841104

219. Kirchhoff J, Raven N, Boes A, Roberts JL, Russell S, Treffenfeldt W, et al. Monoclonal tobacco cell lines with enhanced recombinant protein yields can be generated from heterogeneous cell suspension cultures by flow sorting. Plant Biotechnol J (2012) 10:93644. doi:10.1111/j.1467-7652.2012. 00722.x

220. Khoudi H, Laberge S, Ferullo JM, Bazin R, Darveau A, Castonguay $\mathrm{Y}$, et al. Production of a diagnostic monoclonal antibody in perennial alfalfa plants. Biotechnol Bioeng (1999) 64:135-43. doi:10.1002/ (SICI) 1097-0290(19990720)64: $2<135::$ AID-BIT2 $>3.3 . \mathrm{CO} ; 2-\mathrm{H}$

221. Ma JK, Hikmat BY, Wycoff K, Vine ND, Chargelegue D, Yu $\mathrm{L}$, et al. Characterization of a recombinant plant monoclonal secretory antibody and preventive immunotherapy in humans. Nat Med (1998) 4:601-6. doi:10.1038/ nm0598-601

222. Larrick JW, Yu L, Chen J, Jaiswal S, Wycoff K. Production of antibodies in transgenic plants. Res Immunol (1998) 149:603-8. doi: 10.1016/S0923-2494(98)80013-8

223. Wycoff KL. Secretory IgA antibodies from plants. Curr Pharm Des (2005) 11:2429-37. doi:10.2174/ 1381612054367508

224. McCormick AA. Tobacco derived cancer vaccines for non-Hodgkin's lymphoma: perspectives and progress. Hum Vaccin (2011) 7:305-12. doi:10.4161/hv.7.3.14163

225. Horneff G, Becker W, Wolf F, Kalden JR, Burmester GR. Human anti-murine immunoglobulin antibodies as disturbing factors in TSH determination. Klin Wochenschr (1991) 69:220-3. doi:10.1007/BF01646945

226. Horneff G, Winkler T, Kalden JR, Emmrich F, Burmester GR. Human anti-mouse antibody response induced by anti-CD4 monoclonal antibody therapy in patients with rheumatoid arthritis. Clin Immunol Immunopathol (1991) 59:89-103. doi:10.1016/ 0090-1229(91)90084-N

227. Castilla J, Pintado B, Sola I, Sánchez-Morgado JM, Enjuanes L. Engineering passive immunity in transgenic mice secreting virusneutralizing antibodies in milk. Nat Biotechnol (1998) 16:349-54. doi:10.1038/nbt0498-349

228. Castilla J, Sola I, Pintado B, Sánchez-Morgado JM, Enjuanes L. Lactogenic immunity in transgenic mice producing recombinant antibodies neutralizing coronavirus. Adv Exp Med Biol (1998) 440:675-86. doi:10.1007/ 978-1-4615-5331-1_87

229. Limonta J, Pedraza A, Rodríguez A, Freyre FM, Barral AM, Castro FO, et al. Production of active anti-CD6 mouse/human chimeric antibodies in the milk of transgenic mice. Immunotechnology (1995) 1:107-13. doi:10.1016/ 1380-2933(95)00010-0

230. Newton DL, Pollock D, DiTullio P, Echelard Y, Harvey M, Wilburn B, et al. Antitransferrin receptor antibody-RNase fusion protein expressed in the mammary gland of transgenic mice. J Immunol Methods (1999) 231:159-67. doi:10.1016/S00221759(99)00154-4

231. Gavin WG, Pollock D, Fell P, Yelton D, Cammuso C, Harrington $\mathrm{M}$, et al. Expression of the antibody hBR96-2 in the milk of transgenic mice and production of hBR96-2 transgenic goats. Theriogenology (1997) 47:214. doi: 10.1016/S0093-691X(97)82341-2

232. Zhu L, van de Lavoir M-C Albanese J, Beenhouwer DO, Cardarelli PM, Cuison S, et al. Production of human monoclonal antibody in eggs of chimeric chickens. Nat Biotechnol (2005) 23:1159-69. doi:10.1038/nbt1132

233. Brüggemann M, Caskey HM, Teale C, Waldmann H, Williams GT, Surani MA, et al. A repertoire of monoclonal antibodies with human heavy chains from transgenic mice. Proc Natl Acad Sci U S A (1989) 86:6709-13. doi:10.1073/ pnas.86.17.6709

234. Kuroiwa $Y$, Kasinathan $P$, Choi YJ, Naeem R, Tomizuka K, Sullivan EJ, et al. Cloned transchromosomic calves producing human immunoglobulin. Nat Biotechno (2002) 20:889-94. doi:10.1038/ nbt727

235. Kuroiwa Y, Kasinathan P, Matsushita H, Sathiyaselan J, Sullivan EJ, Kakitani M, et al. Sequential targeting of the genes encoding immunoglobulin-mu and prion protein in cattle. Nat Genet (2004) 36:775-80. doi:10.1038/ng1373

236. Richt JA, Kasinathan P, Hamir AN, Castilla J, Sathiyaseelan T,
Vargas F, et al. Production of cattle lacking prion protein. Nat Biotechnol (2007) 25:132-8. doi: 10.1038/nbt1271

237. Kuroiwa Y, Kasinathan P, Sathiyaseelan T, Jiao J, Matsushita $\mathrm{H}$, Sathiyaseelan J, et al. Antigenspecific human polyclonal antibodies from hyperimmunized cattle. Nat Biotechnol (2009) 27:173-81. doi:10.1038/nbt.1521

238. Grosse-Hovest L, Müller S, Minoia R, Wolf E, Zakhartchenko V, Wenigerkind $\mathrm{H}$, et al. Cloned transgenic farm animals produce a bispecific antibody for $\mathrm{T}$ cell-mediated tumor cell killing. Proc Natl Acad Sci U S A (2004) 101:6858-63. doi:10.1073/ pnas.0308487101

239. Flisikowska T, Thorey IS, Offner S, Ros F, Lifke V, Zeitler B, et al. Efficient immunoglobulin gene disruption and targeted replacement in rabbit using zinc finger nucleases. PLoS ONE (2011) 6:e21045. doi:10.1371/journal. pone. 0021045

240. Mendicino M, Ramsoondar J, Phelps C, Vaught T, Ball S, LeRoith T, et al. Generation of antibody- and B cell-deficient pigs by targeted disruption of the J-region gene segment of the heavy chain locus. Transgenic Res (2011) 20:625-41. doi:10.1007/ s11248-010-9444-z

241. Ramsoondar J, Mendicino M, Phelps C, Vaught T, Ball S, Monahan J, et al. Targeted disruption of the porcine immunoglobulin kappa light chain locus. Transgenic Res (2011) 20:643-53. doi:10. 1007/s11248-010-9445-y

242. Houdebine L-M. Production of pharmaceutical proteins by transgenic animals. Comp Immunol Microbiol Infect Dis (2009) 32:107-21. doi:10.1016/j.cimid.2007.11.005

243. Green LL, Hardy MC, MaynardCurrie CE, Tsuda H, Louie DM, Mendez MJ, et al. Antigen-specific human monoclonal antibodies from mice engineered with human Ig heavy and light chain YACs. Nat Genet (1994) 7:13-21. doi:10. 1038/ng0594-13

244. Lonberg N, Huszar D. Human antibodies from transgenic mice. Int Rev Immunol (1995) 13:65-93. doi:10.3109/08830189509061738

245. Pruzina S, Williams GT, Kaneva G, Davies SL, Martín-López A, Brüggemann $M$, et al. Human monoclonal antibodies to HIV1 gp140 from mice bearing 
YAC-based human immunoglobulin transloci. Protein Eng Des Sel (2011) 24:791-9. doi:10.1093/ protein/gzr038

246. Osborn MJ, Ma B, Avis S, Binnie A, Dilley J, Yang X, et al. High-affinity IgG antibodies develop naturally in Ig-knockout rats carrying germline human $\mathrm{IgH} / \mathrm{Ig} \kappa / \operatorname{Ig} \lambda$ loci bearing the rat $\mathrm{CH}$ region. $J$ Immunol (2013) 190:1481-90. doi: 10.4049/jimmunol.1203041

247. Chen C, Snedecor B, Nishihara JC, Joly JC, McFarland N, Andersen DC, et al. High-level accumulation of a recombinant antibody fragment in the periplasm of Escherichia coli requires a triplemutant (degP prc spr) host strain. Biotechnol Bioeng (2004) 85:46374. doi:10.1002/bit.20014

248. Monsellier E, Bedouelle H. Improving the stability of an antibody variable fragment by a combination of knowledge-based approaches: validation and mechanisms. J Mol Biol (2006) 362:58093. doi:10.1016/j.jmb.2006.07.044

249. Rahbarizadeh F, Rasaee MJ, Forouzandeh-Moghadam M, Allameh A-A. High expression and purification of the recombinant camelid anti-MUC1 single domain antibodies in Escherichia coli. Protein Expr Purif (2005) 44:32-8. doi:10.1016/j.pep.2005.04.008

250. Hussack G, Arbabi-Ghahroudi M, van Faassen $\mathrm{H}$, Songer JG, Ng KK-S, MacKenzie R, et al. Neutralization of Clostridium difficile toxin A with single-domain antibodies targeting the cell receptor binding domain. J Biol Chem (2011) 286:8961-76. doi:10.1074/ jbc.M110.198754

251. Carter P, Kelley RF, Rodrigues ML, Snedecor B, Covarrubias $M$, Velligan $\mathrm{MD}$, et al. High level Escherichia coli expression and production of a bivalent humanized antibody fragment. Biotechnology (N $\quad Y)$ (1992) 10:163-7.

252. Cossins AJ, Harrison S, Popplewell AG, Gore MG. Recombinant production of a VL single domain antibody in Escherichia coli and analysis of its interaction with peptostreptococcal protein L. Protein Expr Purif (2007) 51:253-9. doi:10. 1016/j.pep.2006.07.013

253. Quintero-Hernández V, JuárezGonzález VR, Ortíz-León M, Sánchez R, Possani LD, Becerril B. The change of the scFv into the Fab format improves the stability and in vivo toxin neutralization capacity of recombinant antibodies. Mol
Immunol (2007) 44:1307-15. doi: 10.1016/j.molimm.2006.05.009

254. Yang T, Yang L, Chai W, Li R, Xie J, Niu B. A strategy for highlevel expression of a single-chain variable fragment against TNF $\alpha$ by subcloning antibody variable regions from the phage display vector pCANTAB 5E into pBV220. Protein Expr Purif (2011) 76:10914. doi:10.1016/j.pep.2010.10.006

255. King DJ, Byron OD, Mountain A, Weir N, Harvey A, Lawson AD, et al. Expression, purification and characterization of B72.3 Fv fragments. Biochem J (1993) 290( $\mathrm{Pt}$ 3):723-9.

256. Ye T, Lin Z, Lei H. High-level expression and characterization of an anti-VEGF165 single-chain variable fragment $(\mathrm{scFv})$ by small ubiquitin-related modifier fusion in Escherichia coli. Appl Microbiol Biotechnol (2008) 81:311-7. doi: 10.1007/s00253-008-1655-3

257. Nadkarni A, Kelley L-LC, Momany C. Optimization of a mouse recombinant antibody fragment for efficient production from Escherichia coli. Protein Expr Purif (2007) 52:219-29. doi:10.1016/j. pep.2006.10.011

258. Padiolleau-Lefevre S, Alexandrenne C, Dkhissi F, Clement G, Essono S, Blache C, et al. Expression and detection strategies for an $\mathrm{scFv}$ fragment retaining the same high affinity than Fab and whole antibody: implications for therapeutic use in prion diseases. Mol Immunol (2007) 44:1888-96. doi:10.1016/j.molimm.2006.09. 035

259. Philibert P, Stoessel A, Wang W, Sibler A-P, Bec N, Larroque C, et al. A focused antibody library for selecting scFvs expressed at high levels in the cytoplasm. BMC Biotechnol (2007) 7:81. doi:10. 1186/1472-6750-7-81

260. Nesbeth DN, Perez-Pardo M-A, Ali S, Ward J, Keshavarz-Moore E. Growth and productivity impacts of periplasmic nuclease expression in an Escherichia coli Fab' fragment production strain. Biotechnol Bioeng (2012) 109:517-27. doi:10. 1002/bit.23316

261. Ueda Y, Tsumoto K, Watanabe K, Kumagai I. Synthesis and expression of a DNA encoding the $\mathrm{Fv}$ domain of an anti-lysozyme monoclonal antibody, HyHEL10, in Streptomyces lividans. Gene (1993) 129:129-34. doi:10.1016/ 0378-1119(93)90708-B

262. Swennen D, Paul M-F, Vernis L, Beckerich J-M, Fournier A,
Gaillardin C. Secretion of active anti-Ras single-chain Fv antibody by the yeasts Yarrowia lipolytica and Kluyveromyces lactis. Microbiology (2002) 148:41-50.

263. Rahbarizadeh F, Rasaee MJ, Forouzandeh M, Allameh A-A. Over expression of anti-MUC1 single-domain antibody fragments in the yeast Pichia pastoris. Mol Immunol (2006) 43:426-35. doi: 10.1016/j.molimm.2005.03.003

264. Ji X, Lu W, Zhou H, Han D, Yang L, Wu $\mathrm{H}$, et al. Covalently dimerized Camelidae antihuman TNFa single-domain antibodies expressed in yeast Pichia pastoris show superior neutralizing activity. Appl Microbiol Biotechnol (2013). doi:10.1007/s00253012-4639-2

265. Ezzine A, M'Hirsi el Adab S, Bouhaouala-Zahar B, Hmila I, Baciou L, Marzouki MN. Efficient expression of the anti-AahI' scorpion toxin nanobody under a new functional form in a Pichia pastoris system. Biotechnol Appl Biochem (2012) 59:15-21. doi:10.1002/bab. 67

266. Maeng BH, Choi J, Sa YS, Shin JH, Kim YH. Functional expression of recombinant anti-BNP scFv in methylotrophic yeast Pichia pastoris and application as a recognition molecule in electrochemical sensors. World J Microbiol Biotechnol (2012) 28:1027-34. doi: 10.1007/s11274-011-0901-5

267. Koliasnikov OV, Grigorenko VG, Egorov AM, Lange S, Schmid RD. Recombinant production of horseradish peroxidase conjugates with Fab antibodies in Pichia pastoris for analytical applications. Acta Naturae (2011) 3:85-92.

268. Schoonooghe S, Kaigorodov V, Zawisza M, Dumolyn C, Haustraete J, Grooten J, et al. Efficient production of human bivalent and trivalent anti-MUC1 FabscFv antibodies in Pichia pastoris. BMC Biotechnol (2009) 9:70. doi: 10.1186/1472-6750-9-70

269. Gorlani A, de Haard H, Verrips T. Expression of VHHs in Saccharomyces cerevisiae. Methods Mol Biol (2012) 911:277-86. doi:10. 1007/978-1-61779-968-6_17

270. Gorlani A, Hulsik DL, Adams H, Vriend G, Hermans P, Verrips T. Antibody engineering reveals the important role of $J$ segments in the production efficiency of llama single-domain antibodies in $\mathrm{Sac}$ charomyces cerevisiae. Protein Eng Des Sel (2012) 25:39-46. doi:10. 1093/protein/gzr057
271. Sommaruga S, Lombardi A, Salvadè $A$, Mazzucchelli $S$, Corsi F, Galeffi P, et al. Highly efficient production of anti-HER2 $s c F v$ antibody variant for targeting breast cancer cells. Appl Microbiol Biotechnol (2011) 91:613-21. doi:10.1007/s00253-011-3306-3

272. Khatri NK, Gocke D, Trentmann O, Neubauer P, Hoffmann F. Singlechain antibody fragment production in Pichia pastoris: benefits of prolonged pre-induction glycerol feeding. Biotechnol J (2011) 6:45262. doi:10.1002/biot.201000193

273. Jafari R, Holm P, Piercecchi M, Sundström BE. Construction of divalent anti-keratin 8 single-chain antibodies ( $\mathrm{sc}(\mathrm{Fv}) 2)$, expression in Pichia pastoris and their reactivity with multicellular tumor spheroids. J Immunol Methods (2011) 364:65-76. doi:10.1016/j. jim.2010.11.003

274. Barnard GC, Kull AR, Sharkey NS, Shaikh SS, Rittenhour AM, Burnina I, et al. High-throughput screening and selection of yeast cell lines expressing monoclonal antibodies. J Ind Microbiol Biotechnol (2010) 37:961-71. doi:10.1007/ s10295-010-0746-1

275. Wang D, Su M, Sun Y, Huang S, Wang J, Yan W. Expression, purification and characterization of a human single-chain Fv antibody fragment fused with the $\mathrm{Fc}$ of an IgG1 targeting a rabies antigen in Pichia pastoris. Protein ExprPurif(2012) 86:75-81. doi:10. 1016/j.pep.2012.08.015

276. Chen M-T, Lin S, Shandil I, Andrews D, Stadheim TA, Choi BK. Generation of diploid Pichia pastoris strains by mating and their application for recombinant protein production. Microb Cell Fact (2012) 11:91. doi:10.1186/14752859-11-91

277. Sotiriadis A, Keshavarz T, Keshavarz-Moore E. Factors affecting the production of a single-chain antibody fragment by Aspergillus awamori in a stirred tank reactor. Biotechnol Prog (2001) 17:618-23. doi:10.1021/bp010026+

278. Gómez-Sebastián S, Nuñez MC, Garaicoechea L, Alvarado C, Mozgovoj M, Lasa R, et al. Rotavirus Aspecific single-domain antibodies produced in baculovirus-infected insect larvae are protective in vivo. BMC Biotechnol (2012) 12:59. doi: 10.1186/1472-6750-12-59

279. Kurasawa JH, Shestopal SA, Jha NK, Ovanesov MV, Lee TK, Sarafanov AG. Insect cell-based 
expression and characterization of a single-chain variable antibody fragment directed against blood coagulation factor VIII. Protein ExprPurif (2013) 88:201-6. doi:10. 1016/j.pep.2012.12.008

280. Backovic M, Johansson DX, Klupp BG, Mettenleiter TC, Persson MAA, Rey FA. Efficient method for production of high yields of Fab fragments in Drosophila S2 cells. Protein Eng Des Sel (2010) 23:16974. doi:10.1093/protein/gzp088

281. Johansson DX, Drakenberg K, Hopmann KH, Schmidt A, Yari F, Hinkula J, et al. Efficient expression of recombinant human monoclonal antibodies in Drosophila S2 cells. J Immunol Methods (2007) 318:37-46. doi:10.1016/j. jim.2006.08.017

282. Gilmartin AA, Lamp B, Rümenapf T, Persson MAA, Rey FA, Krey T. High-level secretion of recombinant monomeric murine and human single-chain Fv antibodies from Drosophila S2 cells. Protein Eng Des Sel (2012) 25:59-66. doi:10.1093/protein/gzr058

283. Palmberger D, Rendic D, Tauber P, Krammer F, Wilson IBH, Grabherr R. Insect cells for antibody production: evaluation of an efficient alternative. J Biotechnol (2011) 153:160-6. doi:10.1016/j. jbiotec.2011.02.009

284. Nettleship JE, Ren J, Rahman N, Berrow NS, Hatherley D, Neil Barclay A, et al. A pipeline for the production of antibody fragments for structural studies using transient expression in HEK 293T cells. Protein Expr Purif (2008) 62:83-9. doi:10.1016/j.pep.2008.06.017

285. Codamo J, Munro TP, Hughes BS, Song M, Gray PP. Enhanced $\mathrm{CHO}$ cell-based transient gene expression with the epi-CHO expression system. Mol Biotechnol (2011) 48:109-15. doi:10.1007/ s12033-010-9351-9

286. Van Berkel PHC, Gerritsen J, van Voskuilen E, Perdok G, Vink T, van de Winkel JGJ, et al. Rapid production of recombinant human IgG with improved ADCC effector function in a transient expression system. Biotechnol Bioeng (2010) 105:350-7. doi:10.1002/bit.22535
287. Wulhfard S, Baldi L, Hacker DL, Wurm F. Valproic acid enhances recombinant mRNA and protein levels in transiently transfected Chinese hamster ovary cells. J Biotechnol (2010) 148:128-32. doi: 10.1016/j.jbiotec.2010.05.003

288. Backliwal G, Hildinger M, Kuettel I, Delegrange F, Hacker DL, Wurm FM. Valproic acid: a viable alternative to sodium butyrate for enhancing protein expression in mammalian cell cultures. Biotechnol Bioeng (2008) 101:182-9. doi: 10.1002/bit.21882

289. Wulhfard S, Tissot S, Bouchet S, Cevey J, de Jesus M, Hacker $\mathrm{DL}$, et al. Mild hypothermia improves transient gene expression yields several fold in Chinese hamster ovary cells. Biotechnol Prog (2008) 24:458-65. doi:10. 1021/bp070286c

290. Mader A, Prewein B, Zboray K, Casanova E, Kunert R. Exploration of BAC versus plasmid expression vectors in recombinant CHO cells. Appl Microbiol Biotechnol (2012) 97(9):4049-54. doi:10. 1007/s00253-012-4498-x

291. Kober L, Zehe C, Bode J. Optimized signal peptides for the development of high expressing $\mathrm{CHO}$ cell lines. Biotechnol Bioeng (2013) 110:1164-73. doi:10.1002/ bit. 24776

292. Spens E, Häggström L. Defined protein and animal componentfree NS0 fed-batch culture. Biotechnol Bioeng (2007) 98:118394. doi:10.1002/bit.21509

293. Burky JE, Wesson MC, Young A, Farnsworth S, Dionne B, Zhu Y, et al. Protein-free fedbatch culture of non-GS NS0 cell lines for production of recombinant antibodies. Biotechnol Bioeng (2007) 96:281-93. doi:10.1002/bit. 21060

294. Tchoudakova A, Hensel F, Murillo A, Eng B, Foley M, Smith L, et al. High level expression of functional human IgMs in human PER.C6 cells. MAbs (2009) 1:163-71. doi: 10.4161/mabs.1.2.7945

295. Agrawal V, Slivac I, Perret S, Bisson L, St-Laurent G, Murad Y, et al. Stable expression of chimeric heavy chain antibodies in $\mathrm{CHO}$ cells. Methods Mol Biol (2012) 911:287-303. doi:10.1007/978-161779-968-6_18

296. Huang L, Li M-X, Lei Y, Wang Y-T, Xie K, Yang Y-L, et al Expression, purification and activity determination of humanized anti-HER2 monoclonal antibody in CHO. Chin Pharm J (2012) 47:884-8.

297. Tran M, Van C, Barrera DJ, Pettersson PL, Peinado CD, Bui J, et al. Production of unique immunotoxin cancer therapeutics in algal chloroplasts. Proc Natl Acad Sci US A (2013) 110:E15-22. doi:10.1073/ pnas. 1214638110

298. Almquist KC, McLean MD, Niu Y, Byrne G, Olea-Popelka FC, Murrant C, et al. Expression of an anti-botulinum toxin A neutralizing single-chain Fv recombinant antibody in transgenic tobacco. Vaccine (2006) 24: 2079-86. doi:10.1016/j.vaccine. 2005.11.014

299. Sainsbury F, Sack M, Stadlmann J, Quendler H, Fischer R, Lomonossoff GP. Rapid transient production in plants by replicating and non-replicating vectors yields high quality functional anti-HIV antibody. PLoS ONE (2010) 5:e13976. doi:10. 1371/journal.pone.0013976

300. Cui L, Peng H, Zhang R, Chen Y, Zhao L, Tang K. Recombinant $\mathrm{hHscFv}-\mathrm{RC}-\mathrm{RNase}$ protein derived from transgenic tobacco acts as a bifunctional molecular complex against hepatocellular carcinoma. Biotechnol Appl Biochem (2012) 59:323-9. doi:10. 1002/bab.1039

301. Huang Z, Phoolcharoen W, Lai H, Piensook K, Cardineau G, Zeitlin L, et al. High-level rapid production of full-size monoclonal antibodies in plants by a single-vector DNA replicon system. Biotechno Bioeng (2010) 106:9-17. doi:10. 1002/bit.22652

302. Zhang R, Cui D, Wang $\mathrm{H}$, Li C, Yao X, Zhao Y, et al. Functional recombinant human antiHBV antibody expressed in milk of transgenic mice. Transgenic Res (2012) 21:1085-91. doi:10.1007/ s11248-012-9589-z
303. Wei J, Yang X, Zheng M, Wang M, Dai Y, Chen Z, et al. The recombinant chimeric antibody chHAb18 against hepatocellular carcinoma can be produced in milk of transgenic mice. Transgenic Res (2011) 20:321-30. doi:10. 1007/s11248-010-9408-3

304. Zhang R, Rao M, Li C, Cao J, Meng Q, Zheng $\mathrm{M}$, et al. Functional recombinant human anti-HAV antibody expressed in milk of transgenic mice. Transgenic Res (2009) 18:445-53. doi:10. 1007/s11248-008-9241-0

305. Yuskevich V, Khodarovich Y, Kagarliskiy G, Stremovskiy O, Maksimenko O, Lukash S, et al. Expression of humanized anti-Her2/neu single-chain IgGl-like antibody in mammary glands of transgenic mice. Biochimie (2011) 93: 628-30. doi:10.1016/j.biochi.2010. 12.001

306. Kamihira M, Kawabe Y, Shindo T, Ono K, Esaka K, Yamashita T, et al. Production of chimeric monoclonal antibodies by genetically manipulated chickens. J Biotechnol (2009) 141:18-25. doi:10.1016/j. jbiotec.2009.02.022

Conflict of Interest Statement: The authors declare that the research was conducted in the absence of any commercial or financial relationships that could be construed as a potential conflict of interest.

Received: 25 March 2013; accepted: 15 July 2013; published online: 29 July 2013. Citation: Frenzel A, Hust $M$ and Schirrmann $T$ (2013) Expression of recombinant antibodies. Front. Immunol. 4:217. doi: 10.3389/fimmu.2013.00217

This article was submitted to Frontiers in B Cell Biology, a specialty of Frontiers in Immunology.

Copyright (c) 2013 Frenzel, Hust and Schirrmann. This is an open-access article distributed under the terms of the Creative Commons Attribution License, which permits use, distribution and reproduction in other forums, provided the original authors and source are credited and subject to any copyright notices concerning any third-party graphics etc. 